\title{
Infectious optic neuropathies: a clinical update
}

This article was published in the following Dove Press journal:

Eye and Brain

28 September 2015

Number of times this article has been viewed

\section{Rim Kahloun \\ Nesrine Abroug \\ Imen Ksiaa \\ Anis Mahmoud \\ Hatem Zeghidi \\ Sonia Zaouali \\ Moncef Khairallah \\ Department of Ophthalmology, Fattouma Bourguiba University Hospital, Faculty of Medicine, University of Monastir, Monastir, Tunisia}

Correspondence: Moncef Khairallah Department of Ophthalmology, Fattouma Bourguiba University Hospital, 5019 Monastir, Tunisia

$\mathrm{Tel}+2167346$ II 44

Fax +21673460678

Email moncef.khairallah@rns.tn

\begin{abstract}
Different forms of optic neuropathy causing visual impairment of varying severity have been reported in association with a wide variety of infectious agents. Proper clinical diagnosis of any of these infectious conditions is based on epidemiological data, history, systemic symptoms and signs, and the pattern of ocular findings. Diagnosis is confirmed by serologic testing and polymerase chain reaction in selected cases. Treatment of infectious optic neuropathies involves the use of specific anti-infectious drugs and corticosteroids to suppress the associated inflammatory reaction. The visual prognosis is generally good, but persistent severe vision loss with optic atrophy can occur. This review presents optic neuropathies caused by specific viral, bacterial, parasitic, and fungal diseases.
\end{abstract}

Keywords: optic neuropathy, viruses, bacteria, parasites, fungi, vaccination

\section{Introduction}

Optic nerve involvement with variable visual impairment has been associated with a wide variety of infectious disorders. ${ }^{1-3}$ It may present as anterior optic neuritis, also called papillitis (swollen optic disc), retrobulbar optic neuritis (normal optic disc), neuroretinitis (optic disc edema with macular star), anterior ischemic optic neuropathy, or as another form of optic neuropathy.

The pathogenesis of infectious optic neuropathies remains speculative. Direct involvement of the optic nerve by a pathogen and indirect involvement with inflammatory, degenerative, or vascular mechanisms might contribute to the development of optic nerve involvement. ${ }^{1-3}$

The purpose of this article is to review optic neuropathies caused by specific viral, bacterial, parasitic, and fungal diseases.

\section{Viral optic neuropathies Herpes viruses}

Herpes simplex virus (types I and 2)

Optic neuropathy can occur in association with herpes simplex virus encephalitis, as well as with acute retinal necrosis (ARN) syndrome. ARN syndrome is defined by a combination of clinical features, including areas of retinal necrosis, occlusive vasculopathy, vitritis, and anterior chamber inflammation. This entity is characterized by a high rate of complications, including retinal detachment, optic nerve or macular involvement, and fellow eye disease. ${ }^{4}$ Optic neuropathy has been reported in $11 \%-57 \%$ of ARN cases. ${ }^{4-6}$ Optic nerve involvement in ARN may occur before, after, 
or simultaneously with retinal necrosis and usually causes a rapid and severe vision loss. ${ }^{7-9}$ It may present as papillitis (Figure 1), neuroretinitis, retrobulbar optic neuropathy, or optic disc atrophy that may develop several weeks after acute ARN. ${ }^{4}$ Several mechanisms have been postulated for the pathogenesis of optic nerve involvement in ARN, including intraneural vasculitis, compressive ischemia of the optic nerve, and inflammation and necrosis due to direct herpes virus infection. ${ }^{4}$

Acyclovir appears to be efficacious in the treatment of ARN-associated optic neuropathy. The role of systemic corticosteroids in improving visual outcome is not well established. However, it is important to ensure that the infectious disease has been properly covered with antiviral therapy prior to initiation of corticosteroid therapy. ${ }^{4}$

\section{Varicella zoster virus}

Varicella zoster virus (VZV) is responsible for two distinct clinical entities, ie, varicella zoster and herpes zoster. Varicella, often occurring in childhood, is the primary infection, and herpes zoster, most commonly seen among elderly or immunocompromised patients, is due to recurrent disease. Papillitis associated with varicella has been reported to occur in children and adults, during or after the onset of varicella rash. ${ }^{10-16}$ Visual loss is usually bilateral and can be severe. A few cases of papillitis preceding the onset of varicella rash have been reported. ${ }^{13}$ Visual outcome of varicella-associated papillitis is generally good, with complete restoration of visual acuity, although there may be residual optic disc pallor. ${ }^{10-13}$ However, severe persistent visual loss has been reported. ${ }^{14,15}$

The role of corticosteroid therapy in the management of varicella-associated optic neuritis is controversial. Systemic corticosteroids have been advocated to accelerate visual

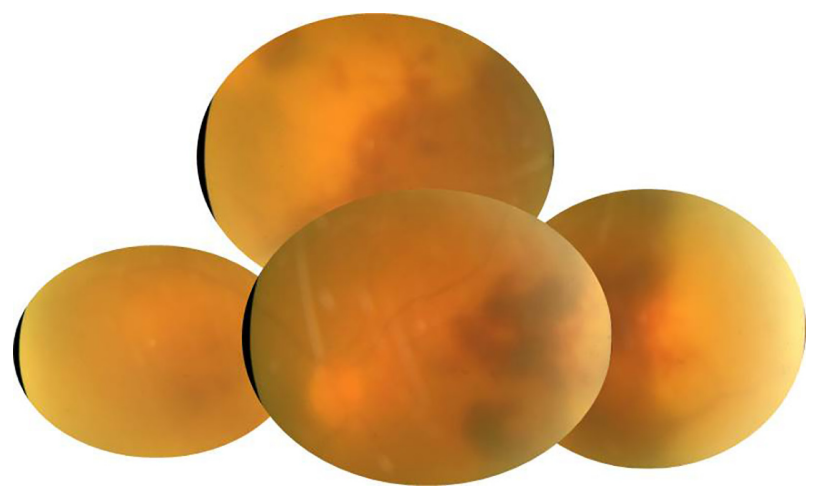

Figure I Fundus photograph of the left eye of a patient with HSVI-associated acute retinal necrosis shows marked optic disc edema associated with peripheral areas of retinal necrosis and retinal hemorrhages.

Abbreviation: HSVI, herpes simplex virus type I. recovery, but there are reports of patients who recovered spontaneously without corticosteroid therapy or had severe residual visual loss despite corticosteroid therapy. ${ }^{10,14,15}$ The role of antiviral therapy is not established either.

Optic neuropathy in the form of anterior or retrobulbar optic neuritis is a rare complication of herpes zoster ophthalmicus. It may occur simultaneously to the acute vesicular rash or, more frequently, as a postherpetic complication, weeks to months after disease onset. ${ }^{17-26}$ Visual acuity may vary from severe bilateral impairment to moderate unilateral impairment, with a normal or edematous optic disc. Good recovery from herpes zoster ophthalmicus optic neuritis with systemic acyclovir and corticosteroid therapy has been reported; however, cases of visual loss due to optic disc atrophy may occur. ${ }^{18}$ Giant cell arteritis is the main differential diagnosis of VZV-associated optic neuropathy, mainly in elderly patients without skin rash. A normal erythrocyte sedimentation rate and $\mathrm{C}$-reactive protein level along with a negative temporal artery biopsy can rule out giant cell arteritis. Optic nerve involvement in herpes zoster might be caused by direct infection of the nerve or an ischemic process due to inflammatory thrombosis. ${ }^{18}$ Other VZV-related ocular conditions that may be accompanied by optic nerve involvement include ARN syndrome and progressive outer retinal necrosis (PORN). PORN is a necrotizing herpetic retinopathy usually seen in immunocompromised patients and is caused by VZV. Optic nerve involvement has been reported in $17 \%$ of eyes with PORN including optic disc edema and optic disc atrophy. ${ }^{24}$ Retrobulbar optic neuropathy has been reported to precede the development of PORN. ${ }^{25,26}$ Eyes with PORN-associated optic neuropathy have a poor visual outcome despite aggressive antiviral therapy.

\section{Cytomegalovirus (herpesvirus 5)}

Cytomegalovirus (CMV) papillitis has been reported in $4 \%-14 \%$ of patients with acquired immune deficiency syndrome and CMV retinitis. ${ }^{27-30}$ Several cases of CMV optic neuropathy in immune-compromised patients unrelated to CMV retinitis have also been described, including isolated optic neuritis, retrobulbar optic neuritis associated with meningoencephalitis and bilateral PORN, and bilateral retrobulbar optic neuritis following haploidentical hematopoietic stem cell transplantation. ${ }^{31-35}$ A few cases of bilateral CMV papillitis without associated retinitis have been reported in young immunocompetent patients, with good recovery after antiviral therapy with or without associated corticosteroid therapy. ${ }^{36-38}$ The prognosis of CMV-associated papillitis remains guarded despite aggressive antiviral therapy with or 
without associated corticosteroid therapy, with final visual acuity less than $20 / 68$ in almost all patients. ${ }^{27-30}$

\section{Epstein-Barr virus (herpesvirus 6)}

The Epstein-Barr virus causes infectious mononucleosis in childhood and adolescence. It is also associated with Burkitt's lymphoma, primary cerebral lymphoma in patients with acquired immune deficiency syndrome, and nasopharyngeal carcinoma. Optic nerve involvement in Epstein-Barr virus infection is generally bilateral and may include papillitis, retrobulbar optic neuritis, and neuroretinitis. ${ }^{39-41} \mathrm{~A}$ few cases of chiasmal involvement have been also reported. ${ }^{42,43}$ Most cases had a good visual outcome after oral or intravenous corticosteroid therapy. ${ }^{39-41}$

\section{Human immunodeficiency virus}

Human immunodeficiency virus (HIV) is a retrovirus and a member of the genus Lentivirus within the family Retroviridae. ${ }^{2}$ Primary HIV optic nerve involvement is rare and may be the presenting manifestation of the disease. ${ }^{44}$ However, it should remain a diagnosis of exclusion to be considered only after ruling out opportunistic infections and neoplastic conditions.

HIV optic neuropathy may be unilateral or bilateral and may present as retrobulbar optic neuropathy, papillitis, ischemic optic neuropathy, or optic disc pallor. ${ }^{2,44-50}$ Inflammatory, vascular, and degenerative mechanisms have been postulated to play a role in the pathogenesis of HIV-associated optic neuropathy. Histopathologic studies of affected optic nerves have demonstrated axonal degeneration and demyelination, and glial changes involving hypertrophic astrocytes, vacuolated oligodendrocytes, and mononuclear phagocyte series cells. ${ }^{51,52}$ These findings suggest that optic nerve degeneration may be mediated by HIV-infected macrophages. HIV-associated optic neuropathy may be treated with antiretroviral drugs, corticosteroids, and tumor necrosis factor antagonists. ${ }^{44,45,50}$

\section{Arboviruses West Nile virus}

West Nile virus (WNV) is an enveloped single-stranded RNA virus of the family Flaviviridae, genus Flavivirus that is transmitted to humans by an infected mosquito vector of the genus Culex, with wild birds serving as its reservoir. ${ }^{53}$ Most human infections are subclinical or manifest as febrile illness. ${ }^{53}$ However, severe neurologic disease, frequently associated with advanced age and diabetes, was reported to occur in less than $1 \%$ of patients. ${ }^{53} \mathrm{~A}$ bilateral or rarely unilateral multifocal chorioretinitis with linear clustering of chorioretinal lesions is the most common finding, occurring in almost $80 \%$ of patients with acute WNV infection associated with neurologic illness. ${ }^{54,55}$

Optic nerve involvement, with or without associated chorioretinitis, has been described in association with WNV infection. ${ }^{2,53-61}$ It may present in the form of optic neuritis, neuroretinitis, optic disc swelling, optic disc staining on fluorescein angiography, or papilledema due to intracranial hypertension caused by meningoencephalitis., ${ }^{2,53-62}$

To date, there is no effective treatment for WNV infection. In cases of severe systemic disease, intensive supportive therapy is indicated. The overall prognosis of optic nerve involvement in WNV infection is good, although persistent visual loss may occur due to optic atrophy.

\section{Chikungunya}

Chikungunya fever is an emergent infectious disease caused by Chikungunya virus, and transmitted by the bite of the infected Aedes mosquitoes. Systemic involvement includes acute fever with headache, fatigue, myalgia, diffuse maculopapular rash, bleeding from the nose or gums, peripheral edema, joint pain neurological signs, acute hepatic failure, and multiorgan failure. ${ }^{56}$ Ocular involvement is common, and may include episcleritis, anterior uveitis, retinitis, retinochoroiditis, mild vitritis, occlusive vasculitis, central retinal artery occlusion, exudative retinal detachment, and optic nerve involvement. ${ }^{56}$ Optic neuropathy is one of the most important causes of acute vision loss in patients with Chikungunya. It may occur simultaneously with systemic infection, suggesting a direct viral mechanism, or later in the course of the disease, suggesting an immune-mediated reaction. ${ }^{63}$ Various clinical forms of optic neuropathy have been described including unilateral or bilateral papillitis, retrobulbar neuritis, and neuroretinitis. ${ }^{56,63-69}$ The overall visual outcome of Chikungunya-associated optic neuritis is good, and corticosteroid therapy seems to accelerate recovery when initiated at an early stage of the disease. .6,67 $^{6}$

\section{Dengue fever}

Dengue fever is an arthropod vector-borne disease caused by the Dengue virus, a Flavivirus transmitted by the Aedes mosquito. ${ }^{56}$ Systemic disease may range from mild febrile illness to life-threatening disease, such as Dengue hemorrhagic fever and Dengue shock syndrome. ${ }^{56}$ Ocular involvement may include subconjunctival hemorrhage, anterior uveitis, vitritis, retinal hemorrhages, retinal vascular sheathing, yellow subretinal dots, retinal pigment epithelium mottling, foveolitis, 
retinochoroiditis, choroidal effusion, panophthalmitis, oculomotor nerve palsy, and optic nerve involvement. ${ }^{56,70}$ Optic nerve involvement may include neuroretinitis, optic disc swelling, and optic neuritis. ${ }^{56,70-78}$ The reported incidence of optic neuritis ranges from $0 \%$ to $1.5 \% .{ }^{71}$ Optic neuritis may be bilateral or unilateral, isolated, or associated with Dengue maculopathy. Spontaneous visual recovery is possible in Dengue fever-associated optic neuritis, but severe permanent visual loss has been reported. ${ }^{72,76}$ Self-limited single cases of bilateral neuroretinitis and neuromyelitis optica have been also reported. ${ }^{77,78}$

\section{Rift valley fever}

Rift valley fever is an arthropod-borne viral disease caused by Bunyaviridae and transmitted to humans through a bite by infected mosquitoes or through direct contact with infected animals. ${ }^{56}$ Systemic involvement includes fever with a biphasic temperature curve, headache, arthralgia, myalgia, and gastrointestinal disturbances. ${ }^{56}$ Severe clinical presentations may include a hemorrhagic fever with liver involvement, thrombocytopenia, icterus and bleeding tendencies, and a neurological involvement with encephalitis after a febrile episode with confusion and coma. ${ }^{56}$

Ocular involvement includes anterior uveitis, macular or paramacular necrotizing retinitis, retinal hemorrhages, vitritis, retinal vasculitis, and optic nerve involvement. ${ }^{56,79,80}$ Optic nerve involvement includes optic disc edema, reported in $15 \%$ of patients in the acute phase, and optic atrophy, reported in $20 \%$ of cases during follow-up. ${ }^{79}$

\section{Other viruses}

\section{Influenza}

A few cases of optic neuritis in the setting of influenza infection have been reported. The visual outcome was good after corticosteroid therapy. ${ }^{81-85}$ Neuroretinitis and neuromyelitis optica with a self-limited course have also been reported. ${ }^{83,85}$ Optic nerve involvement may be related to direct viral infection or due to an autoimmune event triggered by infection. The association with other neurological complications, including extrapyramidal syndrome, Guillain-Barré syndrome, myelitis and myositis, ${ }^{82}$ and improvement after systemic corticosteroid therapy may argue in favor of the latter hypothesis.

\section{Mumps}

Mumps is an acute contagious viral disease of the parotid salivary glands, characterized by swelling of the affected parts, fever, and pain beneath the ear, which commonly affects children. Optic nerve involvement is rare in mumps, and may include papillitis, retrobulbar optic neuritis, and neuroretinitis. ${ }^{86-90}$ Optic nerve involvement is usually bilateral and occurs 2-5 weeks after parotiditis. ${ }^{86,87}$ Visual impairment is usually severe, with recovery during the following month, but there may be permanent vision loss with optic atrophy. ${ }^{86}$

\section{Rubella}

Rubella is a common infectious disease caused by the rubella virus. The disease is generally mild in children but has serious consequences in pregnant women, causing fetal death or congenital rubella syndrome. Symptoms include rash, low fever, nausea, and mild conjunctivitis. The rash, occurring in $50 \%-80 \%$ of cases, starts on the face and neck and then progress down the body. Swollen lymph glands behind the ears and in the neck are the most characteristic clinical feature of rubella infection. Infected adults, more commonly women, may develop arthritis and painful joints that usually last from 3 to 10 days.

A few cases of optic neuritis related to rubella infection have been reported. ${ }^{91-93}$ A delayed onset of optic neuritis after the initial infection and a prompt response to corticosteroid therapy may suggest involvement of an immune process in the pathogenesis of post-rubella optic neuritis.

\section{Measles}

Measles is a highly contagious infection caused by the measles virus. Signs and symptoms of measles include cough, runny nose, sore throat, fever, and a red, blotchy skin rash. Optic nerve involvement, including optic neuritis and retrobulbar optic neuropathy, is a rare complication of measles that may affect children or adults with or without associated encephalomyelitis. ${ }^{94-98}$ Optic neuritis usually occurs about 1 week after the onset of initial symptoms. The prognosis is generally favorable with recovery of good visual acuity after corticosteroid therapy. ${ }^{94-98}$

\section{Bacterial optic neuropathies Cat scratch disease}

Cat scratch disease (CSD), or ocular Bartonellosis, is a worldwide zoonotic infectious disease caused by the Gramnegative bacillus Bartonella henselae, and is transmitted to humans by the scratches, licks, or bites of an infected cat, particularly a kitten. ${ }^{99}$ The systemic illness, which occurs mainly in children and young adults, is typically self-limited and usually presents as a flu-like syndrome and a tender lymphadenitis involving the lymph nodes draining dermal or conjunctival sites of inoculation. ${ }^{100}$ Ocular involvement 
can occur in 5\%-10\% of patients with CSD. ${ }^{101}$ The eye can be involved either with the primary inoculation complex, resulting in the Parinaud oculoglandular syndrome or by hematogenous spread leading to an array of ocular manifestations, including neuroretinitis, inner retinitis, and occlusive vasculitis. ${ }^{99,101}$

Neuroretinitis was found to be the most characteristic and common posterior segment manifestation of CSD, occurring in $49 \%-71 \%$ of cases. ${ }^{102-105}$ Conversely, CSD is the most common identifiable cause of neuroretinitis (two thirds of cases). ${ }^{99,100}$ The ocular condition is usually unilateral, although bilateral cases have also been reported. The onset of visual symptoms usually follows the inoculation by approximately 4 weeks and the systemic symptoms by $2-3$ weeks. Typically, the patient presents with decreased vision, with visual acuity ranging from 20/20 to light perception. A relative afferent papillary defect, dyschromatopsia, and a visual field defect are usually seen. Mild anterior chamber and vitreous inflammation is also common. Fundus examination typically shows optic disc edema associated with a partial or complete macular star (Figure 2). The optic disc edema occurs approximately 1 week prior to the development of stellate maculopathy, which therefore may be absent at the time of initial presentation. The optic nerve involvement leads to peripapillary retinal thickening and, frequently, an exudative retinal detachment. ${ }^{106}$ Intraretinal hemorrhages or telangiectatic vessels may be seen. ${ }^{102}$ A multifocal inner retinitis or chorioretinitis, typically juxtavascular in location, may accompany the disc swelling. ${ }^{103,104}$ Rarely, a large inflammatory mass or exudate of the optic nerve head may be seen. ${ }^{107}$ Fluorescein angiography shows leakage from the optic disc with no evidence of capillary abnormality in the macular area. ${ }^{108}$ Optical coherence tomography may be helpful in detecting subclinical serous retinal detachment. Neuroretinitis usually has a self-limited course. Most patients recover excellent visual acuity over a period of several weeks to months (20/40 or better in $65 \%-80 \%$ of eyes). ${ }^{104,105,109,110}$ However, significant visual morbidity may occur. ${ }^{105}$ The macular star usually resolves in approximately 8-12 weeks, but it may be present for up to 1 year. A few patients may be left with mild pallor of the optic disc. ${ }^{111}$ Retinal pigment epithelial changes may also develop after resolution of macular hard exudates. The diagnosis of CSD is based on clinical findings and laboratory tests, including indirect fluorescent antibody test, enzyme-linked immunoassay, Western blot, and polymerase chain reaction (PCR)-based assays. ${ }^{99,100,112-114}$

Until now, there are no guidelines for the treatment of CSD or its ocular complications. Treatment is recommended
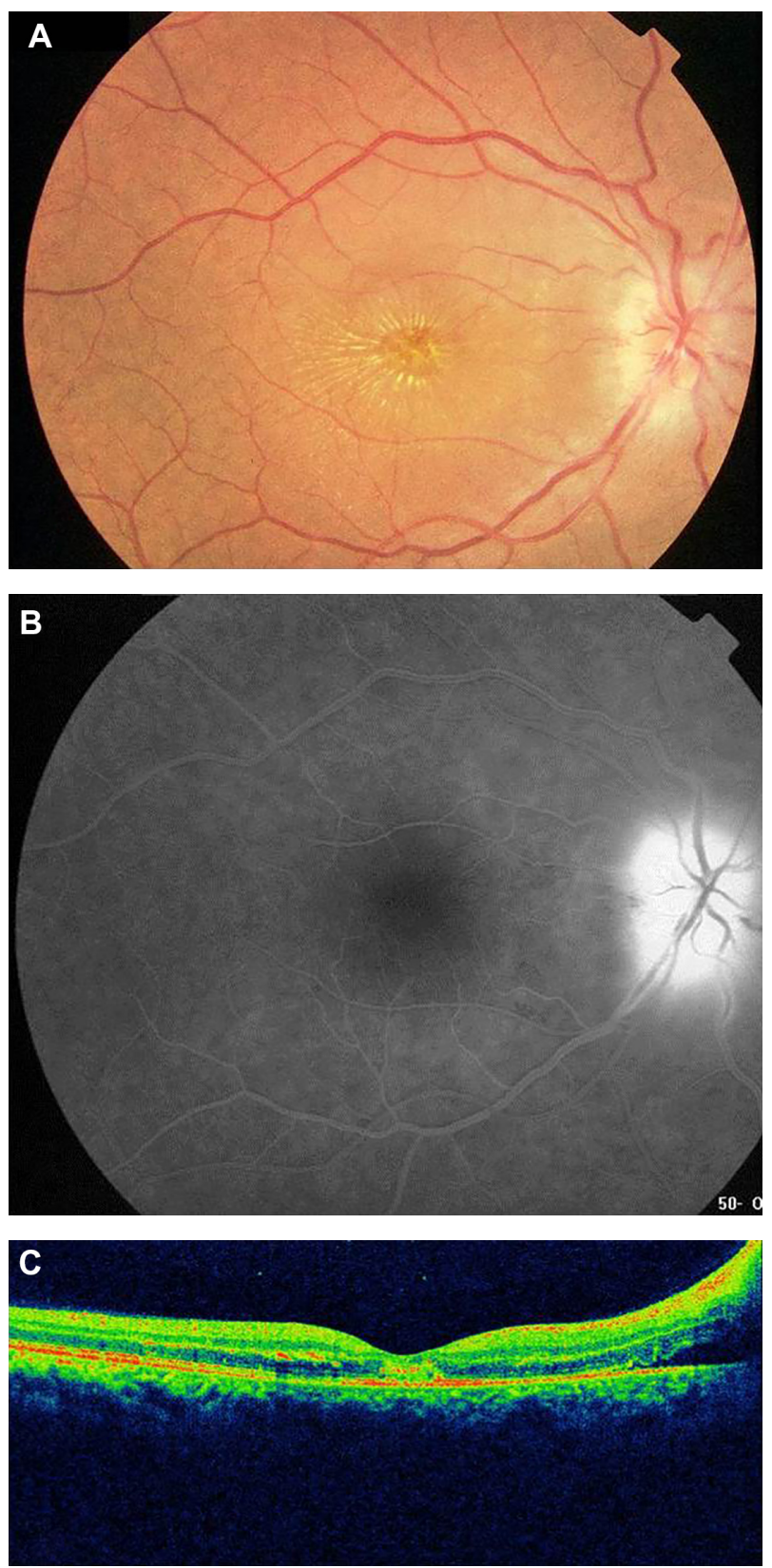

Figure 2 (A) Fundus photograph of the right eye of a patient with cat scratch disease showing optic disc edema and a complete macular star consistent with a diagnosis of neuroretinitis. (B) Late-phase fluorescein angiogram shows optic disc leakage with no abnormalities in the macular area. (C) Optical coherence tomography shows peripapillary serous retinal detachment.

for severe ocular or systemic complications of $B$. henselae infection. A typical regimen consists of doxycycline $100 \mathrm{mg}$ twice daily for 4-6 weeks in immunocompetent patients and 4 months in immunocompromised patients. ${ }^{115-117}$ It seems to shorten the course of infection and hasten visual recovery. ${ }^{104}$ However, a few other studies suggest that there is no association between final visual acuity and the use of systemic antibiotics. ${ }^{105,110}$ The role of corticosteroids in the treatment of ocular CSD remains unclear. ${ }^{111}$ Some authors recommend 
the early use of corticosteroids as they may hasten recovery and other authors failed to support the use of corticosteroid therapy in CSD optic neuropathy. ${ }^{105,118}$

\section{Tuberculosis}

Tuberculosis (TB) is an infectious disease caused by Mycobacterium tuberculosis, mainly affecting the lungs, and is histologically characterized by caseating granulomas. Intraocular TB usually occurs in the absence of evident active systemic disease. ${ }^{119}$ TB may affect all ocular tissues and may manifest as anterior granulomatous uveitis, choroiditis, retinal vasculitis, subretinal abscess, endophthalmitis, panophthalmitis, or optic neuropathy. ${ }^{119,120}$ Optic nerve involvement is a common complication of ocular TB. It may result from direct mycobacterial infection, by contiguous spread from the choroid or hematogenous dissemination, or from a hypersensitivity to the infectious agent. ${ }^{120}$ The clinical spectrum of tuberculous optic neuropathy is wide, with papillitis (51.6\%), neuroretinitis (14.5\%), and optic nerve tubercle (11.3\%; Figure 3) being the most common clinical form. ${ }^{121}$ Associated posterior uveitis or panuveitis may be seen in almost $90 \%$ of cases. Extraocular tuberculosis, particularly pulmonary and meningeal, could be associated in more than one third of patients. ${ }^{121}$ There are reports of compressive optic neuropathy, anterior ischemic optic neuropathy, optic atrophy, and optic chiasmatic arachnoiditis. ${ }^{122-132}$ TB should also be considered in the differential diagnosis of apparently isolated papillitis or neuroretinitis, particularly in patients from endemic areas. In such cases, indocyanine green angiography may show subclinical choroidal involvement. ${ }^{121}$ Tubercular choroidal lesions may develop later as well in the course of optic neuropathy. ${ }^{127}$ Unilateral optic disc swelling may be secondary to tubercular posterior scleritis. ${ }^{122}$ Patients with central nervous system TB, particularly tubercular meningitis (hydrocephalus), optic chiasmatic arachnoiditis, and optochiasmatic tuberculoma, may develop papilledema and, in advanced cases, bilateral optic atrophy. ${ }^{123,124,132}$

The diagnosis of tuberculous optic neuropathy is often presumptive, based on suggestive ocular features, positive results of ocular or systemic investigations, exclusion of other specific causes of uveitis, and a positive response to anti-tubercular treatment. ${ }^{119}$

Management of ocular TB involves the use of antitubercular treatment for 9-12 months. ${ }^{119}$ The use of adjunctive systemic corticosteroid therapy may help reduce the inflammatory reaction, but its beneficial effect and safety remains controversial. ${ }^{120,121,133}$ Tuberculous arachnoiditis may be treated with neurosurgical decompression of the anterior

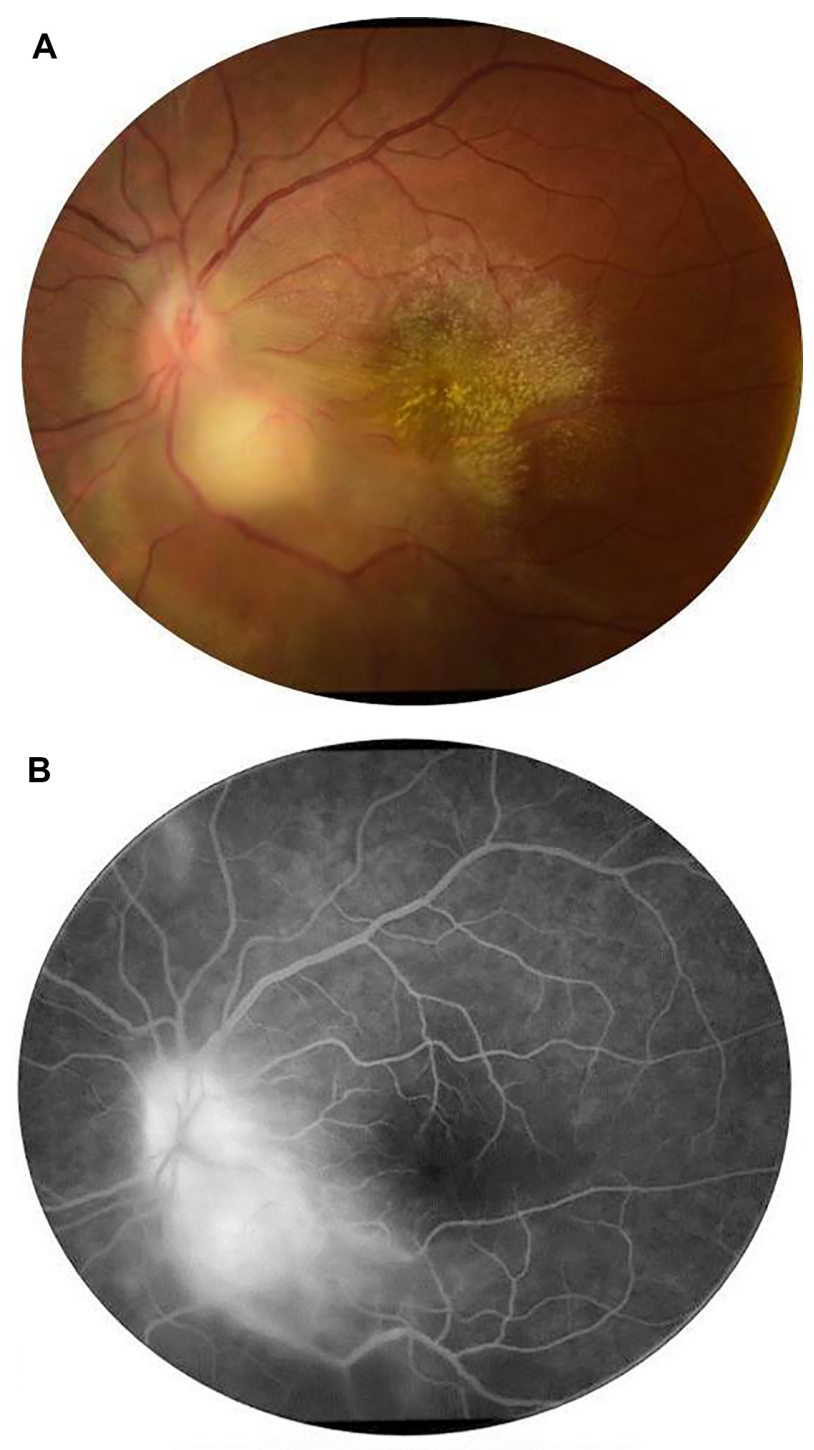

Figure 3 (A) Fundus photograph of the left eye of a patient with ocular tuberculosis shows a juxtapapillary choroidal granuloma with associated papillitis. Note the exudative retinal detachment surrounding the choroidal granuloma and the macular exudates. (B) Late-phase fluorescein angiogram shows leakage of the optic disc and granuloma.

visual pathways. ${ }^{131}$ Visual outcomes of tuberculous optic neuropathy are generally good, with $76.7 \%$ of eyes achieving final visual acuities of $20 / 40$ or better, and complete or partial recovery of visual field defects in $63.2 \%$ of eyes. ${ }^{121}$

\section{Syphilis}

Syphilis is a sexually transmitted disease caused by the spirochete Treponema pallidum, and is known as "the great mimicker" due to its wide variety of clinical presentations. ${ }^{134,135}$ A broad spectrum of ophthalmic manifestations may occur in both acquired and congenital syphilis, including uveitis, scleritis, episcleritis, dacyroadenitis, interstitial keratitis, vitritis, chorioretinitis, retinal vasculitis, serous retinal 
detachment, optic neuropathy, and cranial nerve palsies. ${ }^{135}$ Ocular involvement is strongly suggestive of central nervous system disease and should be considered synonymous with neurosyphilis. ${ }^{134,135}$ Unilateral or bilateral optic neuropathy may occur in secondary and tertiary syphilis, often with minimal or no anterior segment inflammation. It may manifest as papillitis, perineuritis, chiasmal syndrome, gumma of the optic disc, neuroretinitis, and optic disc cupping. ${ }^{136-142}$ Serodiagnosis is usually based on the results of both nontreponemal antigen tests, such as the Venereal Disease Research Laboratory and rapid plasma reagin, and specific treponemal antigen tests, such as the fluorescent treponemal antibody absorption assay and T. pallidum particle agglutination test. ${ }^{143}$ PCR analysis of intraocular and/or cerebrospinal fluid may be useful to confirm syphilitic infection. ${ }^{144}$ The recommended treatment for ocular syphilis, as for neurosyphilis, involves intravenous penicillin $\mathrm{G}$ or intramuscular procaine penicillin for $10-14$ days along with oral probenecid. ${ }^{145}$ Systemic or periocular corticosteroids may be a useful adjunct to antimicrobial agents. ${ }^{146}$

\section{Lyme disease}

Lyme disease (LD) or Lyme borreliosis is an emerging tick-borne infection caused by Borrelia burgdorferi. The spirochete is transmitted to humans by tick bites of the genus Ixodes during the peak season of May to September. ${ }^{147}$ The disease has a bimodal distribution, with peaks in children aged 5-14 years and in adults aged 50-59 years. ${ }^{147,148}$ Three clinical stages of LD are described, including early (local), disseminated, and late (persistent) stages. ${ }^{147}$ A protean of ocular manifestations may occur and vary with each stage. It may include conjunctivitis, keratitis, posterior scleritis, dacryoadenitis, orbital myositis, uveitis, retinal vasculitis, multifocal choroiditis, and neuro-ophthalmic manifestations. ${ }^{148}$

Optic neuropathy has been reported to occur in the early and disseminated stages of LD, most often with bilateral involvement. Besides papilledema associated with meningoencephalitis in children, optic nerve involvement, including papillitis, neuroretinitis, ischemic optic neuropathy, optic atrophy, and chiasmal syndrome, has been described in patients with positive Lyme serology, but causality links remains controversial. ${ }^{149-156}$ In endemic areas, where residents are often seropositive for Borrelia but are asymptomatic, a causal relationship between the disease and the optic neuropathy is difficult to establish. ${ }^{156}$ The diagnosis of LD is based on history, clinical presentation, and supportive serology. Furthermore, other causes of the disease should be excluded. Lack of standardization of cut-off value and cross-reactivity with other spirochetes may lead to false positive and false negative test results. The Centers for Disease Control and Prevention recommend a two-step protocol for the diagnosis of active disease or previous infection: enzymelinked immunosorbent assay for immunoglobulin (Ig)M and $\mathrm{IgG}$, followed by Western immunoblot testing. ${ }^{157}$ PCR analysis of a variety of tissues, including ocular fluids, can be useful. Cerebrospinal fluid pleocytosis with demonstration of intrathecal synthesis of specific antibodies is a mainstay of the diagnosis of Lyme neuroborreliosis in Europe. ${ }^{147}$ The route and duration of antibiotic treatment for presumed optic nerve involvement in LD has not been established. However, optic neuropathy associated with LD is best regarded as a manifestation of central nervous system involvement and requires intravenous antibiotic therapy with ceftriaxone $(2 \mathrm{~g}$ intravenously once daily) for at least 3 weeks.

\section{Rickettsioses}

Rickettsioses are zoonoses due to a group of obligate intracellular small Gram-negative bacteria and are distributed worldwide. Most of them are transmitted to humans by the bite of contaminated arthropods, such as ticks. ${ }^{158}$ A recent syndromic classification distinguishes three major categories of rickettsial diseases: the exanthematic rickettsioses syndrome with a low probability of inoculation eschar; the rickettsioses syndrome with a probability of inoculation eschar; and their variants. ${ }^{159}$ Systemic disease is characterized by the triad of high fever, headache, and skin rash, with or without associated inoculation eschar, termed "tache noire" or dark spot.

Ocular involvement in rickettsioses is common, with retinitis, retinal vasculitis, and optic nerve involvement being the most common ocular manifestations. ${ }^{160-164}$ Other findings have been described, including Parinaud oculoglandular syndrome, conjunctivitis, keratitis, non-granulomatous anterior uveitis, panuveitis, cranial nerve palsies, and endophthalmitis. ${ }^{160-164}$ Rickettsial optic nerve involvement may present in the form of optic disc swelling, optic disc staining on fluorescein angiography, optic neuritis, neuroretinitis (Figure 4), ischemic optic neuropathy, papilledema, and optic atrophy (Figure 5). ${ }^{165-171}$

The exact mechanism of optic neuropathy is unknown, but it may be due to an immune-mediated inflammation or ischemia from endothelial injury and tissue necrosis, reflecting the tropism of rickettsial organisms for optic disc vasculature. ${ }^{170,171}$ Diagnosis of rickettsial infection is made on the basis of epidemiological data, history, systemic symptoms and signs, and the pattern of ocular involvement. It is 


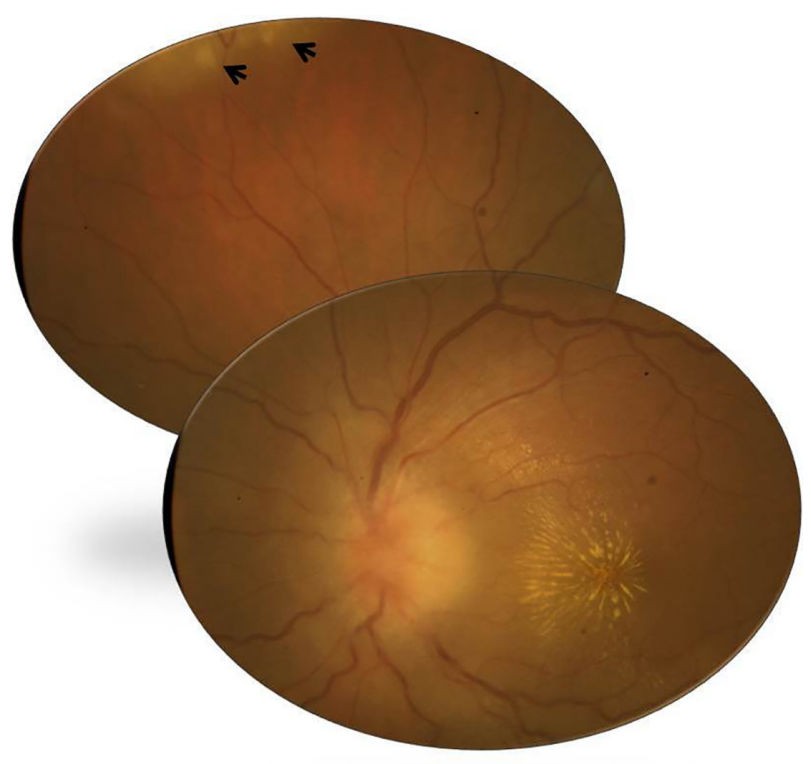

Figure 4 Fundus photograph of the left eye of a patient with rickettsial disease shows optic disc edema and a macular star. Note the presence of foci of inner retinitis in the superior periphery (arrows).

usually confirmed by positive indirect immunofluorescent antibody test results. Although ophthalmic manifestations of rickettsial disease have a self-limited evolution in most patients, severe persistent visual loss may occur, mainly due to optic neuropathy. ${ }^{160,170,171}$ The role of antibiotic therapy, as well as that of oral corticosteroids, in the course of optic neuropathy remains unknown. ${ }^{159,165}$

\section{Q fever}

Q fever is a worldwide zoonosis caused by Coxiella burnetii, an obligate Gram-negative intracellular bacteria. ${ }^{172}$ Transmission to humans occurs primarily through inhalation of aerosols from contaminated soil or animal waste.

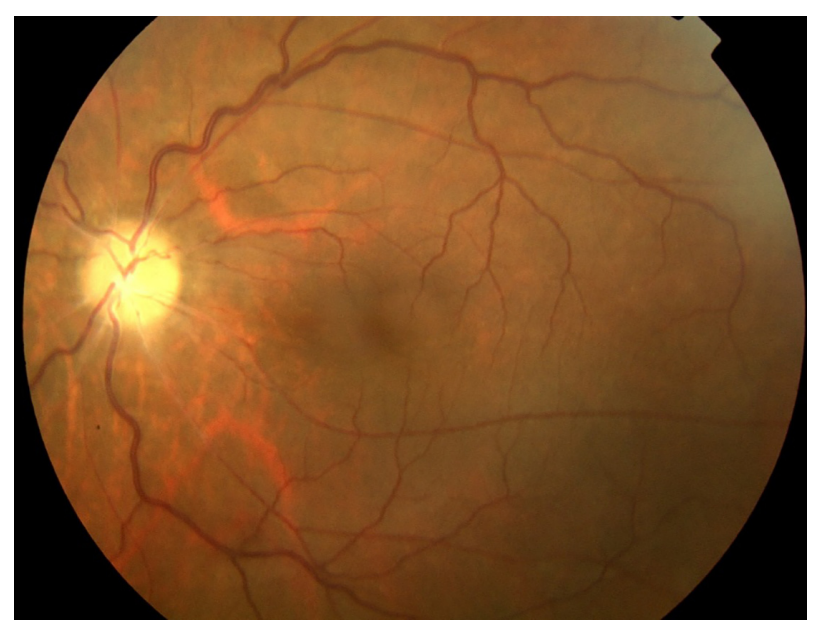

Figure 5 Fundus photograph of the left eye of a patient with a history of rickettsial infection shows optic disc atrophy secondary to ischemic optic neuropathy.
Other rare routes of transmission include tick bites, ingestion of unpasteurized milk or dairy products, and human-tohuman transmission. ${ }^{172}$ The disease has several manifestations, and may be acute or chronic.

Ocular involvement, including optic neuropathy, has rarely been described in the course of $\mathrm{Q}$ fever. ${ }^{173-180}$ The mechanism of optic nerve involvement may be an autoimmune or post-infectious phenomenon. ${ }^{179}$ In most reported cases, optic neuritis was bilateral and occurred either in the acute or chronic stage of the disease. Associated neurological manifestations, including confusion, meningoencephalitis, polyradiculoneuropathy, and cranial nerve palsies, may be seen. ${ }^{179,180}$ The diagnosis of $Q$ fever can be made on the basis of serological testing. Persistent visual loss has been reported in about half of cases. ${ }^{179,180}$ The role of antibiotic and steroid therapy in the management of optic neuritis associated with $\mathrm{Q}$ fever remains unclear.

\section{Whipple's disease}

Whipple's disease is a rare chronic multisystem disease caused by a Gram-positive bacillus, the Tropheryma whippleii. ${ }^{181}$ Ocular involvement, including keratitis, uveitis, retinal vasculitis, cranial nerve palsies, nystagmus, ptosis, and ophthalmoplegia, occurs in about $5 \%$ of patients, usually late in the course of the disease. ${ }^{181-183}$ Other manifestations may include supranuclear gaze palsy and oculomasticatory myoarrhythmia. A few cases of optic neuritis, optic disc edema with subsequent optic atrophy, and orbital involvement with visual loss have been reported. ${ }^{183-185}$ All ocular signs may occur in the absence of gastrointestinal, neurologic, or other systemic manifestations. ${ }^{182}$ The diagnosis of Whipple's disease is challenging, mainly based on cytologic and molecular analysis. ${ }^{183}$ Untreated, the disease can be fatal. Systemic trimethoprim-sulfamethoxazole associated with rifampin, for at least 1 year, is the treatment of choice in central nervous system or ocular Whipple's disease. A prolonged low-dose antibiotic regimen to prevent relapse, neurologic involvement, and death is recommended. ${ }^{183}$ Corticosteroids are usually not required to control intraocular inflammation during antibiotic treatment. ${ }^{183}$

\section{Brucellosis}

Brucellosis is a worldwide zoonosis due to facultative intracellular Gram-negative bacteria, Brucella species. ${ }^{186}$ The disease might be acute or chronic, and a multisystemic involvement occurs in $10 \%-15 \%$ of cases. ${ }^{187}$ Although ocular involvement is uncommon in brucellosis, any ocular structure may be involved, with a broad spectrum of clinical 
findings, including keratitis, uveitis, choroiditis, episcleritis, endophthalmitis, dacryoadenitis, and optic neuropathy. ${ }^{188-200}$ Optic nerve involvement, including optic neuritis and papilledema, has been described in about $10 \%$ of patients with ocular brucellosis. ${ }^{189,192,193}$ It seems that optic neuropathy in brucellosis is secondary to meningeal inflammation (neurobrucellosis) and subsequent axonal degeneration. ${ }^{182,183}$ Ischemic, vasculitic, and immune-mediated mechanisms have also been suggested. ${ }^{188,199}$ The diagnosis of brucellosis relies on clinical features supported by microbiological and serological tests. ${ }^{186,187}$ The visual prognosis of brucella-related optic neuropathy is usually good after an appropriate course of antibiotic and steroid therapy. However, severe cases with permanent visual impairment have been described. ${ }^{199}$

\section{Leptospirosis}

Leptospirosis is a waterborne zoonotic infection caused by a Gram-negative spirochete of the genus Leptospira. ${ }^{201}$ Humans contract the disease by contact with infected urine, tissues, or water. The systemic disease has a biphasic course, with an initial leptospiremic acute phase followed by the immune phase of illness. ${ }^{21,202}$ Ocular involvement may occur in both the acute and second phase of the illness. While in the former phase conjunctival chemosis and scleral icterus are the main ocular findings, the latter immune phase has a broad variety of ocular manifestations, including keratitis, nongranulomatous uveitis, retinal vasculitis, cranial nerves palsies, and optic neuropathy. ${ }^{201-207}$ Optic nerve involvement may present in the form of optic disc hyperemia (seen in 3\%-64\% of cases), optic neuritis, papillitis, or neuroretinitis. ${ }^{202-204,206,207}$

Diagnosis can be established on the basis of laboratory tests including microagglutination test, isolation of the organism from body fluids, and serological and PCR-based assays. ${ }^{201-203}$ Despite the lack of evidence, use of systemic antibiotic therapy is common, whereas corticosteroids are the mainstay of treatment for ocular involvement. ${ }^{202,203,207}$

\section{Leprosy}

Leprosy is a chronic granulomatous infectious disease caused by Mycobacterium leprae. Ocular involvement may include lagophthalmos, corneal involvement, cataract, uveitis, dacryoadenitis, eyelid involvement, and optic nerve involvement. ${ }^{208}$ Optic nerve involvement in the form of papillitis or optic atrophy is a rare complication of leprosy. ${ }^{209-211}$ The pathogenesis of leprosy-associated optic neuropathy is unclear. It might be the result of direct bacterial infection, autoimmune reaction, ischemia, or a combination of these mechanisms. ${ }^{210,211}$ Treatment of leprosy relies on systemic dapsone and rifampin. Corticosteroids have been used for the management of leprosy-associated optic neuropathy. ${ }^{210}$

\section{Other bacterial agents}

Occasional cases of optic neuropathies have been described in other bacterial infections including Ehrlichiosis, anthrax, typhoid fever, pertussis, beta-hemolytic streptococcal infection, and meningococcal, Mycoplasma pneumoniae, Chlamydia, and Klebsiella pneumoniae infections. ${ }^{212-222}$

\section{Optic neuropathies associated with orbital infections}

The term "orbital infections" refers to an invasive bacterial infection of the periorbital and orbital structures. ${ }^{223}$ Orbital infections can develop by extension of infection from adjacent paranasal sinuses or upper respiratory infection, ocular and adnexal structures, direct inoculation as a result of trauma or surgery, or hematogenous spread in the setting of bacteremia. ${ }^{224}$ Optic nerve involvement may occur in the setting of complicated retroseptal infection in the form of orbital abscess or cavernous sinus thrombosis. It may result from direct compression of the optic nerve as well as the nutrient vessels (ischemic optic neuropathy) or dissemination of infection (septic optic neuropathy). ${ }^{225}$

Clinical findings may include decreased visual acuity, afferent pupillary defect, optic disc swelling, retinal venous dilatation, ptosis, severe directional proptosis, periorbital edema, chemosis, ophthalmoplegia, headache, generalized sepsis, nausea, vomiting, and high fever. ${ }^{223}$ Cranio-orbital high-resolution contrast-enhanced computed tomography is the gold standard for diagnosis and management of orbital infections. Treatment involves use of systemic broad-spectrum antibiotics, and is associated with surgical therapy in severe forms of postseptal infection. ${ }^{226}$ The role of corticosteroids in the management of complicated orbital infections remains controversial. The prognosis depends on the rapidity of treatment, but persistent visual loss resulting from rapidly progressing optic neuropathy often occurs.

\section{Parasitic optic neuropathies Toxoplasmosis}

Toxoplasmosis is an infection caused by the intracellular parasite Toxoplasma gondii and is distributed worldwide. Ocular toxoplasmosis is the most common infectious posterior uveitic entity. It typically presents in the form of active unifocal retinochoroiditis usually associated with adjacent old retinochoroidal scar and significant vitritis. 
Atypical presentations of ocular toxoplasmosis mainly include multifocal retinochoroiditis, which is common in immunocompromised individuals, punctate outer or inner retinitis, intraocular inflammation without retinochoroiditis, unilateral pigmentary retinopathy simulating retinitis pigmentosa, Fuchs'-like anterior uveitis, and scleritis. ${ }^{227}$ Reactive optic disc hyperemia usually accompanies active toxoplasmic retinochoroiditis. Lesions adjacent to the optic disc may produce significant morbidity leading to central vision loss or sectorial visual field defects. ${ }^{224}$ In fact, scars within one disc diameter of the disc are more likely to be associated with absolute defects breaking out to the periphery. Other clinical forms of toxoplasmic optic neuropathy include neuroretinitis, papillitis causing vision loss associated with a distant active retinochoroidal lesion, and isolated anterior optic neuritis. ${ }^{228-239}$

The diagnosis of toxoplasmic optic neuritis may be challenging in the absence of an active or inactive retinochoroidal lesion. Diagnosis of toxoplasmic optic neuropathy requires a high index of clinical suspicion and the use of appropriate laboratory investigations. A positive assay for IgG does not confirm the diagnosis of ocular toxoplasmosis, given the high rate of seropositivity in the normal population in most countries. The presence of high IgM and/or IgA titer or a rising $\operatorname{IgG}$ titer indicates recently acquired infection. A negative serology can exclude the diagnosis of ocular toxoplasmosis. The Goldmann-Witmer coefficient and the Western blot technique are used to demonstrate local production of antibodies in aqueous humor or rarely in vitreous fluid. Detection of toxoplasma DNA in ocular fluids by PCR is helpful in atypical cases.

The mechanism of the optic nerve involvement in ocular toxoplasmosis may be the result of direct infection of the optic disc by $T$. gondii or an indirect inflammatory process. $^{228}$

Management of toxoplasmosis-associated optic neuropathy involves the use of a combination of antiparasitic therapy and corticosteroids. The standard treatment includes pyrimethamine, given in a loading dose of $100 \mathrm{mg}$ on day 1 followed by $50 \mathrm{mg}$ daily ( $25 \mathrm{mg}$ in children) and sulfadiazine 4 g/day. ${ }^{227}$ Folinic acid (25 mg per os two or three times a week) is added to prevent bone marrow suppression, which may result from pyrimethamine therapy. Other therapeutic alternatives include oral or intravitreal clindamycin, spiramycin, and azithromycin, and trimethoprim-sulfamethoxazole. The overall visual outcome of toxoplasmosis-associated optic nerve involvement is good after systemic antitoxoplasmosis treatment and corticosteroids. ${ }^{228}$ However, scars within one disc diameter of the optic disc are more likely to be associated with absolute defects leading to considerable field loss (Figure 6). ${ }^{240}$

\section{Toxocariasis}

Toxocariasis is a zoonotic disease caused by the infestation of humans with second-stage larvae of the dog nematode Toxocara canis or the cat nematode Toxocara cati. ${ }^{241}$ Ocular involvement typically presents in the form of retinal granuloma in the periphery or posterior pole, but chronic endophthalmitis can also occur. ${ }^{241,242}$ A few cases of optic neuropathy in the form of papillitis, retrobulbar optic neuritis, or neuroretinitis have been reported in serologically proven toxocariasis. ${ }^{243-247}$ Optic disc granuloma has been reported to occur in $6 \%-19 \%$ of cases. ${ }^{248,249}$ It appears as a yellowish lesion overlying the optic nerve with associated vitritis. Diagnosis of toxocariasis relies on enzyme-linked immunosorbent assay testing, and Goldmann-Witmer coefficient analysis applied to an aqueous humor or vitreous sample may help to establish the diagnosis. Treatment of toxocariasisassociated optic neuropathy involves use of periocular and systemic corticosteroids. ${ }^{245}$ The role of antihelminthic therapy is still controversial.

\section{Diffuse unilateral subacute neuroretinitis}

Diffuse unilateral subacute neuroretinitis is an infectious ocular disease caused by an unidentified motile nematode capable of infiltrating the subretinal space, causing inflammation and retinal degeneration leading to profound vision loss. ${ }^{250}$ Optic disc involvement may be seen in the early stage of the disease, with optic disc edema associated with evanescent, multifocal, yellow-white chorioretinal lesions. ${ }^{250,251}$ The late stage is characterized by profound visual loss, with optic disc atrophy, retinal vessel narrowing, and focal or diffuse retinal pigment epithelium degeneration. ${ }^{250,251}$ Treatment options include laser therapy when the nematode is visible and chemotherapy with anthelmintic drugs, such as mebendazole, thiabendazole, or albendazole when a worm cannot be visualized. ${ }^{252}$ Treatment with corticosteroids has shown transient suppression of the inflammation without altering the final outcome of the disease.

\section{Other parasitic infections}

\section{Onchocerciasis}

Onchocerciasis, also named river blindness or Robles disease, is a parasitic disease caused by the microfilariae Onchocerca volvulus. ${ }^{253}$ Ocular involvement includes punctate keratitis, 

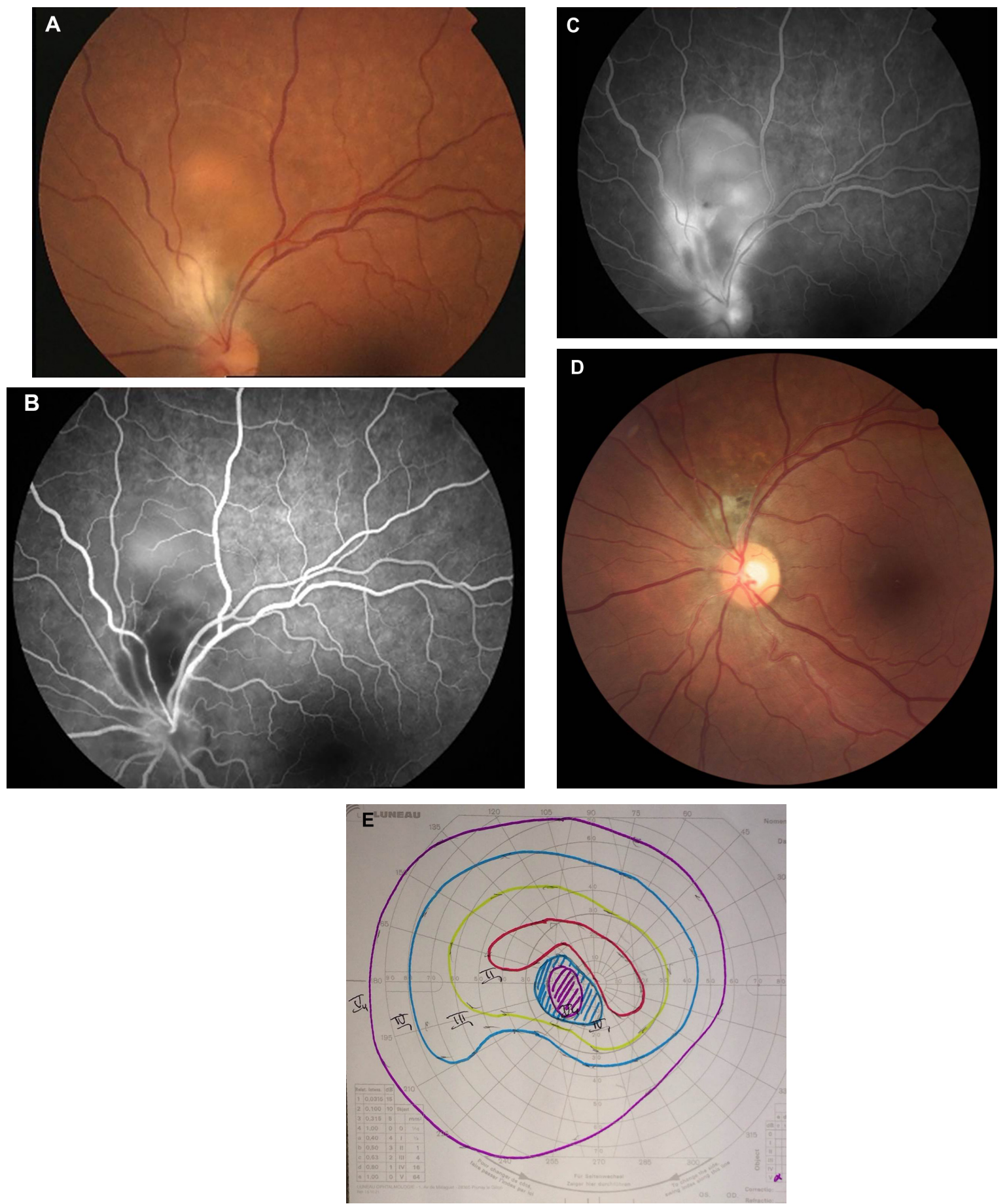

Figure 6 (A) Fundus photograph of the left eye of a patient with ocular toxoplasmosis shows a juxtapapillary active area of retinochoroiditis adjacent to a pigmented scar with associated serous retinal detachment. (B) Early-phase fluorescein angiogram shows hypofluorescence of both active and old foci. (C) Late-phase fluorescein angiogram shows peripheral hyperfluorescence and persistent central hypofluorescence of the active focus of retinochoroiditis with late pooling of dye in the subretinal space and optic disc hyperfluorescence. (D) Fundus photograph 6 months later shows a small atrophic retinochoroidal scar that replaced the active toxoplasmic lesion with a localized defect of the retinal nerve fiber layer as wedge-shaped area running toward the optic disc. (E) Goldmann perimetry shows a persistent scotoma.

corneal opacity, anterior uveitis, and chorioretinal changes, with early disruption of the retinal pigment epithelium and focal areas of atrophy. Later, severe chorioretinal atrophy occurs predominantly in the posterior pole with sheathing of the retinal vessels and optic disc atrophy. ${ }^{253}$ Diagnosis of onchocerciasis is made by extraction of microfilariae or adult worms from skin or subcutaneous nodules by biopsy or by identification of live microfilariae in the aqueous humor. The disease is treated with ivermectin, given in a single oral dose of $150 \mu \mathrm{g} / \mathrm{kg} .{ }^{253}$ 


\section{Malaria}

Malaria is a mosquito-borne infectious disease caused by protists of the genus Plasmodium. Malaria is widespread in tropical regions around the equator, including much of subSaharan Africa, Asia, and the Americas, and is uncommonly seen in developed countries. Ocular involvement in malaria may include retinal hemorrhages and edema, papilledema, disc pallor, vitreous hemorrhage, and cortical blindness. ${ }^{254}$ Optic neuritis is a rare presentation of the disease, and its diagnosis is difficult. ${ }^{255-257}$ The pathogenesis of retrobulbar neuritis is still unknown. It is thought to be possibly the result of tissue hypoxia leading to damage of the optic nerve fibers causing loss of vision. The treatment of optic neuritis due to malaria is not clearly established. Improvement of visual acuity has been reported after malarial treatment associated with corticosteroids. ${ }^{256}$

\section{Angiostrongyliasis}

Angiostrongylus cantonensis is a rare parasitic infection that results in eosinophilic meningitis. The human may be infected by eating raw freshwater snails or other paratenic hosts. ${ }^{258}$ Ocular angiostrongyliasis is a very rare condition, and may include uveitis (with worms in the anterior chamber or in the vitreous), macular edema, retinal edema, necrotic retinitis, panophthalmitis, papilledema, and optic nerve compression. $^{258}$ Optic neuritis is very rare, and sporadic cases have been reported. ${ }^{258-262}$ Optic neuritis caused by A. cantonensis may be treated by surgical removal of the parasites or laser-mediated killing of living worms. ${ }^{258}$ In addition, oral administration of steroids may improve visual acuity by reducing intraocular inflammation. ${ }^{258}$ Anthelmintics, such as albendazole, are not recommended because dead parasites may cause serious intraocular inflammation. ${ }^{258}$ The prognosis for optic neuritis in this condition is not favorable, and only slight improvement of visual acuity occurred after treatment in most cases. ${ }^{258}$

\section{Echinococcosis}

Echinococcosis or hydatid disease is a zoonosis caused by the larval stage of the cestode, genus Echinococcus. Orbital involvement is rare, and the most common symptoms in orbital hydatid cyst are slowly progressive unilateral proptosis, with or without pain, visual deterioration with or without optic disc edema, periorbital pain, headache, and disturbance in ocular mobility. ${ }^{263-265}$ Ultrasonography, computed tomography, and magnetic resonance imaging are diagnostic imaging techniques. The condition may be treated with albendazole or surgical removal of cysts. ${ }^{263-265}$

\section{Fungal optic neuropathies Cryptococcosis}

Cryptococcus neoformans is the most common cause of fungal optic neuropathy, and is related to the acquired immune deficiency syndrome epidemic. Optic neuritis occurs commonly after cryptococcal meningitis and may be either unilateral or bilateral. ${ }^{266-270}$ The optic nerve damage might result from direct invasion of the nerve by the organism, inflammation, ischemia from vasculitis, increased intracranial pressure, or a combination of these factors. A rapid onset of a few hours to a few days is attributed to direct invasion of the optic nerve and its inflammation. A retrobulbar optic neuropathy can also occur. ${ }^{270} \mathrm{Com}-$ monly, patients are already being treated with amphotericin $\mathrm{B}$ and/or fluconazole for cryptococcal meningitis and an increase of the dose can be effective in helping to control the optic nerve involvement. Amphotericin B may be given intravitreally and/or intravenously. A slow onset of visual impairment over a few weeks to a few months was attributed to increased intracranial pressure. Antimicrobial treatment may not be effective in such a situation and optic nerve sheath fenestration may be recommended. ${ }^{271}$

\section{Candidiasis}

Candida species are the most common fungal organisms causing endogenous endophthalmitis in immunocompromised patients. Ocular involvement may include anterior uveitis with multiple, bilateral, white, well circumscribed foci of chorioretinitis. ${ }^{272,273}$ The chorioretinal lesions may be associated with optic disc edema, vasculitis, retinal hemorrhages, and vitreous exudates with a "string-of-pearls" appearance. ${ }^{272,273}$ Diagnosis is based on context and clinical findings and confirmed by positive results on blood or vitreous cultures and/or PCR. Treatment relies on systemic and/or intravitreal antifungal agents (amphotericin B, fluconazole, and voriconazole).

\section{Histoplasmosis}

Presumed ocular histoplasmosis syndrome (POHS) is a multifocal chorioretinitis presumed to be caused by infection with Histoplasma capsulatum, a dimorphic fungus with both yeast and filamentous forms early in life. Diagnosis of POHS is based on the clinical triad of multiple white, atrophic choroidal scars (histo spots), peripapillary pigment changes, and a maculopathy caused by choroidal neovascularization in the absence of anterior chamber or vitreous inflammation. Optic nerve involvement in POHS is characterized by a ring of peripapillary atrophy with a narrow inner pigment zone 
Table I Summary of findings in main infectious optic neuropathies

\begin{tabular}{|c|c|c|c|}
\hline & Optic nerve involvement & $\begin{array}{l}\text { Potential associated } \\
\text { ocular findings }\end{array}$ & Treatment \\
\hline \multicolumn{4}{|c|}{ Viral optic neuropathies } \\
\hline \multicolumn{4}{|l|}{ Herpes viruses } \\
\hline HSV (types I and 2) & $\begin{array}{l}\text { Papillitis, neuroretinitis, retrobulbar optic } \\
\text { neuropathy, and optic disc atrophy }\end{array}$ & $\begin{array}{l}\text { Necrotizing retinitis, vitritis, } \\
\text { arteritis }\end{array}$ & $\begin{array}{l}\text { Acyclovir } \\
\text { Systemic corticosteroids (controversial) }\end{array}$ \\
\hline \multirow[t]{3}{*}{ VZV } & Varicella: papillitis & Anterior uveitis & $\begin{array}{l}\text { Antiviral therapy (controversial) } \\
\text { Systemic corticosteroids (controversial) }\end{array}$ \\
\hline & $\begin{array}{l}\text { HZO: papillitis, retrobulbar optic } \\
\text { neuritis }\end{array}$ & $\begin{array}{l}\text { Skin rash, keratitis, anterior } \\
\text { uveitis, necrotizing retinitis }\end{array}$ & Systemic acyclovir and corticosteroids \\
\hline & $\begin{array}{l}\text { Progressive outer retinal necrosis: optic disc } \\
\text { edema, optic disc atrophy, retrobulbar optic } \\
\text { neuropathy }\end{array}$ & Necrotizing retinitis & Antiviral therapy \\
\hline CMV (herpesvirus 5) & Papillitis, retrobulbar optic neuritis & Retinitis & $\begin{array}{l}\text { Antiviral therapy with or without associated } \\
\text { corticosteroid therapy }\end{array}$ \\
\hline EBV (herpesvirus 6) & $\begin{array}{l}\text { Papillitis, retrobulbar optic neuritis, } \\
\text { neuroretinitis, chiasmal involvement }\end{array}$ & Retinitis, chorioretinitis & Oral or intravenous corticosteroid therapy \\
\hline HIV & $\begin{array}{l}\text { Retrobulbar optic neuropathy, papillitis, } \\
\text { ischemic optic neuropathy, optic disc pallor }\end{array}$ & $\begin{array}{l}\text { Cotton-wool spots, } \\
\text { microaneurysms, retinal } \\
\text { hemorrhages, uveitis }\end{array}$ & $\begin{array}{l}\text { Antiretroviral drugs, corticosteroids, and } \\
\text { tumor necrosis factor antagonists }\end{array}$ \\
\hline \multicolumn{4}{|l|}{ Arboviruses } \\
\hline West Nile virus & $\begin{array}{l}\text { Optic neuritis, neuroretinitis, optic disc } \\
\text { swelling, optic disc staining on fluorescein } \\
\text { angiography, papilledema, optic atrophy }\end{array}$ & Multifocal chorioretinitis & No effective treatment \\
\hline Chikungunya & $\begin{array}{l}\text { Unilateral or bilateral papillitis, } \\
\text { retrobulbar neuritis, neuroretinitis }\end{array}$ & $\begin{array}{l}\text { Retinitis, retinochoroiditis, } \\
\text { mild vitritis, retinal vasculitis }\end{array}$ & Corticosteroid therapy \\
\hline Dengue virus & $\begin{array}{l}\text { Neuroretinitis, optic disc swelling, } \\
\text { optic neuritis, neuromyelitis optica }\end{array}$ & Dengue maculopathy & No specific treatment \\
\hline $\begin{array}{l}\text { Rift valley fever } \\
\text { virus }\end{array}$ & Optic disc edema, optic atrophy & $\begin{array}{l}\text { Anterior uveitis, macular } \\
\text { or paramacular necrotizing } \\
\text { retinitis, retinal hemorrhages, } \\
\text { vitritis, retinal vasculitis }\end{array}$ & Corticosteroid therapy (controversial) \\
\hline \multicolumn{4}{|l|}{ Other viruses } \\
\hline Influenza virus & $\begin{array}{l}\text { Neuroretinitis, neuromyelitis } \\
\text { optica }\end{array}$ & $\begin{array}{l}\text { Retinitis, choroiditis, retinal } \\
\text { hemorrhages }\end{array}$ & Corticosteroid therapy (controversial) \\
\hline Mumps & $\begin{array}{l}\text { Papillitis, retrobulbar optic neuritis, } \\
\text { neuroretinitis, optic atrophy }\end{array}$ & Anterior uveitis & Corticosteroid therapy (controversial) \\
\hline Rubella & Optic neuritis & Anterior uveitis & Corticosteroid therapy (controversial) \\
\hline Measles & $\begin{array}{l}\text { Optic neuritis and retrobulbar } \\
\text { optic neuropathy with or without } \\
\text { associated encephalomyelitis }\end{array}$ & Conjunctivitis, keratitis & Corticosteroid therapy \\
\hline \multicolumn{4}{|c|}{ Bacterial optic neuropathies } \\
\hline Cat scratch disease & Neuroretinitis & Retinitis, retinal vasculitis & $\begin{array}{l}\text { Doxycycline } 100 \mathrm{mg} \text { twice daily for } \\
4-6 \text { weeks in immunocompetent patients and } \\
4 \text { months in immunocompromised patients } \\
\text { Corticosteroid therapy (controversial) }\end{array}$ \\
\hline $\begin{array}{l}\text { Ocular } \\
\text { tuberculosis }\end{array}$ & $\begin{array}{l}\text { Papillitis, neuroretinitis, optic } \\
\text { nerve tubercle, compressive optic } \\
\text { neuropathy, anterior ischemic } \\
\text { optic neuropathy, optic atrophy, } \\
\text { optic chiasmatic arachnoiditis }\end{array}$ & $\begin{array}{l}\text { Choroiditis, retinal } \\
\text { vasculitis, tubercular } \\
\text { choroidal lesions }\end{array}$ & $\begin{array}{l}\text { Anti-tubercular treatment for } 9-12 \text { months } \\
\text { Corticosteroid therapy (controversial) } \\
\text { Neurosurgical decompression of the } \\
\text { anterior visual pathways for optic chiasmatic } \\
\text { arachnoiditis }\end{array}$ \\
\hline Syphilis & $\begin{array}{l}\text { Papillitis, perineuritis, chiasmal } \\
\text { syndrome, gumma of the optic disc, } \\
\text { neuroretinitis, optic disc cupping }\end{array}$ & Retinitis, retinal vasculitis & $\begin{array}{l}\text { Intravenous penicillin } \mathrm{G} \text { or intramuscular } \\
\text { procaine penicillin for } 10-14 \text { days along with } \\
\text { oral probenecid with or without systemic or } \\
\text { periocular corticosteroids }\end{array}$ \\
\hline Lyme disease & $\begin{array}{l}\text { Papilledema, papillitis, neuroretinitis, ischemic } \\
\text { optic neuropathy, chiasmal syndrome }\end{array}$ & Retinitis, retinal vasculitis & $\begin{array}{l}\text { Intravenous ceftriaxone ( } 2 \mathrm{~g} \text { IV once daily) } \\
\text { for at least } 3 \text { weeks }\end{array}$ \\
\hline
\end{tabular}


Table I (Continued)

\begin{tabular}{|c|c|c|c|}
\hline & Optic nerve involvement & $\begin{array}{l}\text { Potential associated } \\
\text { ocular findings }\end{array}$ & Treatment \\
\hline Rickettsioses & $\begin{array}{l}\text { Optic disc swelling, optic disc staining on } \\
\text { fluorescein angiography, optic neuritis, } \\
\text { neuroretinitis, ischemic optic neuropathy, } \\
\text { papilledema, optic atrophy }\end{array}$ & Retinitis, retinal vasculitis & $\begin{array}{l}\text { Doxycycline } 200 \mathrm{mg} / \text { day for } 2 \text { weeks } \\
\text { Corticosteroid therapy (controversial) }\end{array}$ \\
\hline Q fever & Optic neuritis & Retinitis, retinal vasculitis & $\begin{array}{l}\text { Antibiotics and corticosteroid therapy are } \\
\text { controversial }\end{array}$ \\
\hline Whipple's disease & $\begin{array}{l}\text { Optic neuritis, optic disc edema, } \\
\text { optic atrophy }\end{array}$ & Vitritis, retinal vasculitis & $\begin{array}{l}\text { Systemic trimethoprim-sulfamethoxazole } \\
\text { associated with rifampin, for at least I year }\end{array}$ \\
\hline Brucellosis & Optic neuritis, papilledema & Vitritis, choroiditis & Antibiotics and corticosteroid therapy \\
\hline Leptospirosis & $\begin{array}{l}\text { Optic disc hyperemia, optic } \\
\text { neuritis, papillitis, neuroretinitis }\end{array}$ & $\begin{array}{l}\text { Vitritis, retinal vasculitis, } \\
\text { retinal hemorrhages }\end{array}$ & Antibiotics and corticosteroid therapy \\
\hline Leprosy & Papillitis, optic atrophy & $\begin{array}{l}\text { Dacryoadenitis, disorder of } \\
\text { the eyelid, uveitis }\end{array}$ & $\begin{array}{l}\text { Systemic dapsone and rifampin } \\
\text { Systemic corticosteroids }\end{array}$ \\
\hline \multicolumn{4}{|c|}{ Parasitic optic neuropathies } \\
\hline Toxoplasmosis & $\begin{array}{l}\text { Optic disc hyperemia, } \\
\text { neuroretinitis, papillitis, isolated } \\
\text { anterior optic neuritis }\end{array}$ & $\begin{array}{l}\text { Retinochoroiditis, retinal } \\
\text { vasculitis, vitritis }\end{array}$ & $\begin{array}{l}\text { Pyrimethamine ( } 100 \mathrm{mg} \text { on day I followed } \\
\text { by } 50 \mathrm{mg} \text { daily; } 25 \mathrm{mg} \text { in children) and } \\
\text { sulfadiazine } 4 \mathrm{~g} / \text { day with folinic acid } \\
\text { Other alternatives: oral or intravitreal, } \\
\text { clindamycin, spiramycin, azithromycin, } \\
\text { trimethoprim-sulfamethoxazole } \\
\text { Systemic corticosteroids }\end{array}$ \\
\hline Toxocariasis & $\begin{array}{l}\text { Papillitis, retrobulbar optic neuritis, } \\
\text { neuroretinitis, optic disc granuloma }\end{array}$ & Vitritis & Periocular and systemic corticosteroids \\
\hline $\begin{array}{l}\text { Diffuse unilateral } \\
\text { subacute neuroretinitis }\end{array}$ & $\begin{array}{l}\text { Optic disc edema, optic disc } \\
\text { atrophy }\end{array}$ & $\begin{array}{l}\text { Chorioretinitis, retinal vessel } \\
\text { narrowing, focal or diffuse } \\
\text { retinal pigment epithelium } \\
\text { degeneration }\end{array}$ & $\begin{array}{l}\text { Laser therapy, when the nematode is visible, } \\
\text { and chemotherapy with anthelmintic drugs, } \\
\text { such as mebendazole, thiabendazole, or } \\
\text { albendazole when a worm cannot be visualized } \\
\text { Corticosteroid therapy }\end{array}$ \\
\hline \multicolumn{4}{|c|}{ Fungal optic neuropathies } \\
\hline Cryptococcus & $\begin{array}{l}\text { Optic neuritis after cryptococcal meningitis, } \\
\text { retrobulbar optic neuropathy }\end{array}$ & Chorioretinitis & Intravitreal and/or intravenous amphotericin B \\
\hline Candida & $\begin{array}{l}\text { Optic disc edema associated with } \\
\text { chorioretinitis }\end{array}$ & $\begin{array}{l}\text { Chorioretinitis, vasculitis, } \\
\text { retinal hemorrhages, } \\
\text { vitreous exudates }\end{array}$ & $\begin{array}{l}\text { Systemic and/or intravitreal antifungal } \\
\text { agents (amphotericin B, fluconazole, and } \\
\text { voriconazole) }\end{array}$ \\
\hline $\begin{array}{l}\text { Presumed ocular } \\
\text { histoplasmosis } \\
\text { syndrome }\end{array}$ & $\begin{array}{l}\text { Ring of peripapillary atrophy with a } \\
\text { narrow inner pigment zone adjacent to } \\
\text { the disc edge and a white depigmented } \\
\text { zone away from the optic disc }\end{array}$ & $\begin{array}{l}\text { Atrophic choroidal scars, } \\
\text { choroidal neovascularization }\end{array}$ & No specific treatment \\
\hline Aspergillus & Optic neuritis, orbital apex syndrome & & $\begin{array}{l}\text { Intensive antifungal therapy with } \\
\text { amphotericin B, surgical excision of involved } \\
\text { tissue with sinus exenteration }\end{array}$ \\
\hline Mucormycosis & Optic nerve infarction and necrosis & $\begin{array}{l}\text { Proptosis, conjunctival } \\
\text { injection, restricted } \\
\text { extraocular motility }\end{array}$ & Amphotericin B, surgical debridement \\
\hline $\begin{array}{l}\text { Post-vaccination } \\
\text { optic neuropathies }\end{array}$ & $\begin{array}{l}\text { Anterior or retrobulbar optic } \\
\text { neuritis, neuroretinitis }\end{array}$ & & Corticosteroid therapy \\
\hline
\end{tabular}

Abbreviations: CMV, cytomegalovirus; EBV, Epstein-Barr virus; HSV, herpes simplex virus; HIV, human immunodeficiency virus; HZO, herpes zoster ophthalmicus; VZV, varicella zoster virus.

adjacent to the disc edge and a white depigmented zone away from the optic disc. ${ }^{274}$

\section{Aspergillosis}

Aspergillus fumigatus is a ubiquitous and saprophytic agent that becomes pathogenic in case of hypoxic area, which can explain its higher incidence in the paranasal sinuses in immunocompromised patients. A few cases of optic neuritis in the setting of aspergillosis have been reported. ${ }^{275-279}$ The clinical presentation can mimic nonspecific optic neuritis, with a possible good response to corticosteroid therapy. ${ }^{278}$ Several cases of orbital apex syndrome secondary to aspergillus 
are reported. ${ }^{279}$ The pattern of visual field defect depends on anatomical extension of the infection. The diagnosis of ocular aspergillosis might be difficult especially in the early stage. Repeated radiological examination and orbital biopsy may be required in the event of a high level of clinical suspicion. Management of aspergillosis involves prompt surgical excision of the involved tissue with sinus exenteration. Intensive antifungal therapy with amphotericin B is also recommended.

\section{Mucormycosis}

Mucormycosis is an opportunistic fungal infection caused by Mucorales (Mucor, Rhizopus, Absidia, and Cunninghamella). ${ }^{280}$ It is a potentially lethal infection that generally affects immunocompromised patients; however, cases in immunocompetent and diabetic patients have been reported. Rhino-orbito-cerebral mucormycosis presents with nonspecific complaints such as headache, low-grade fever, facial swelling, sinusitis, proptosis, conjunctival injection, and restricted extraocular motility. Optic nerve involvement in mucormycosis includes optic nerve infarction and necrosis that may result from invasion of the blood vessel walls by the organisms, leading to occlusion or thrombosis of the optic nerve sheath, blood vessels, or ophthalmic artery. ${ }^{281-283}$ Direct optic nerve infection by mucormycosis may also occur. Treatment involves aggressive surgical debridement of all involved tissues including exenteration of involved orbits, with prolonged administration of amphotericin B.

\section{Post-vaccination optic neuropathies}

Optic nerve involvement has been described in association with vaccination against various bacterial and virus infections. These include tuberculosis (Bacillus CalmetteGuérin vaccination), influenza virus, hepatitis B virus, hepatitis A virus, yellow fever, measles/rubella vaccines, mumps, diphtheria toxoid, tetanus toxoid, rabies virus, and variola virus. ${ }^{284-301}$

Post-vaccination optic neuritis is a rare event that may occur hours to weeks after vaccination. The presumed pathogenesis of this event is an immune-mediated mechanism.

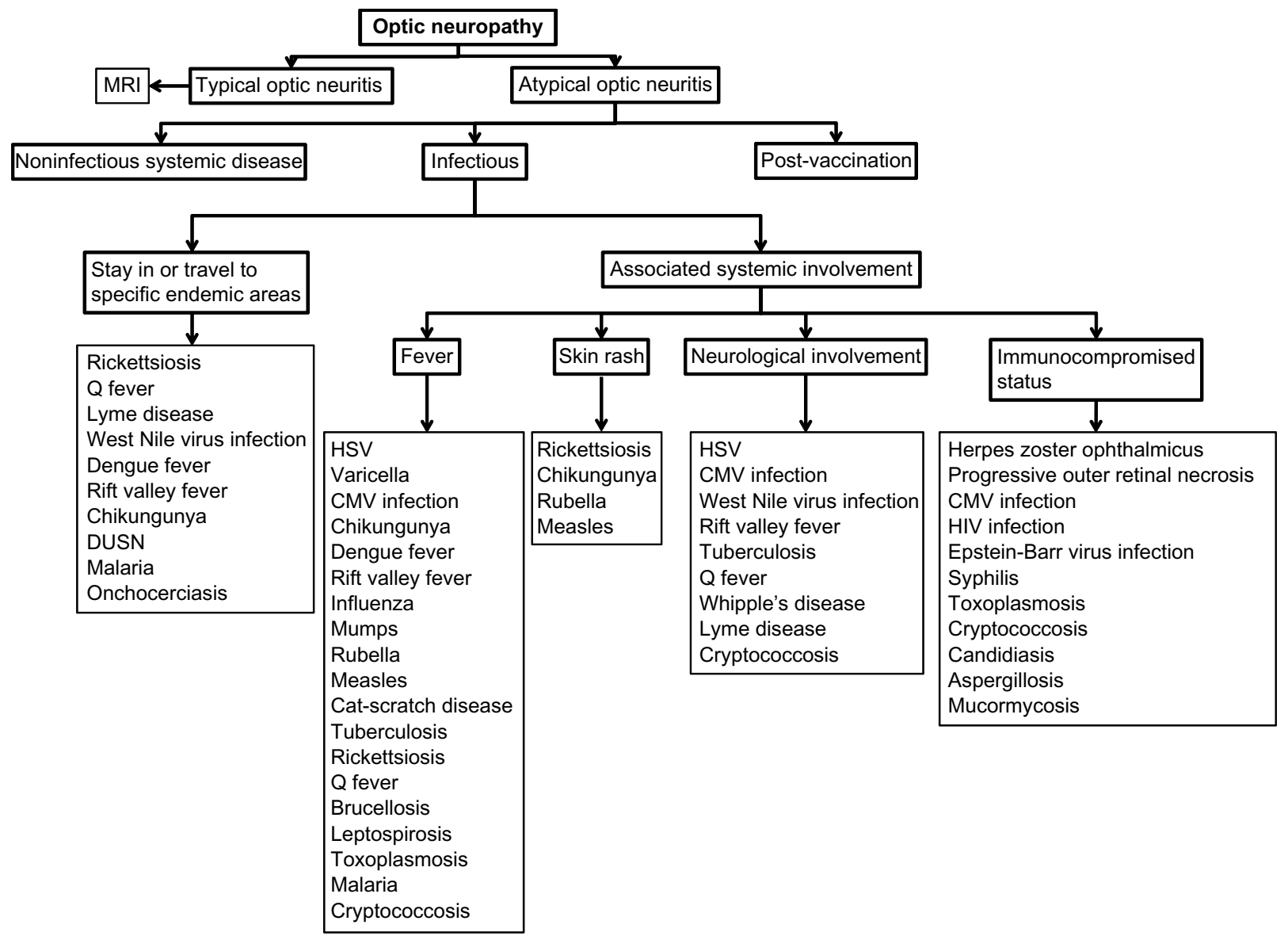

Figure 7 Practical approach to infectious optic neuropathies according to epidemiologic data and associated systemic involvement.

Abbreviations: CMV, cytomegalovirus; DUSN, diffuse unilateral subacute neuroretinitis; HSV, herpes simplex virus; HIV, human immunodeficiency virus; MRI, magnetic resonance imaging. 


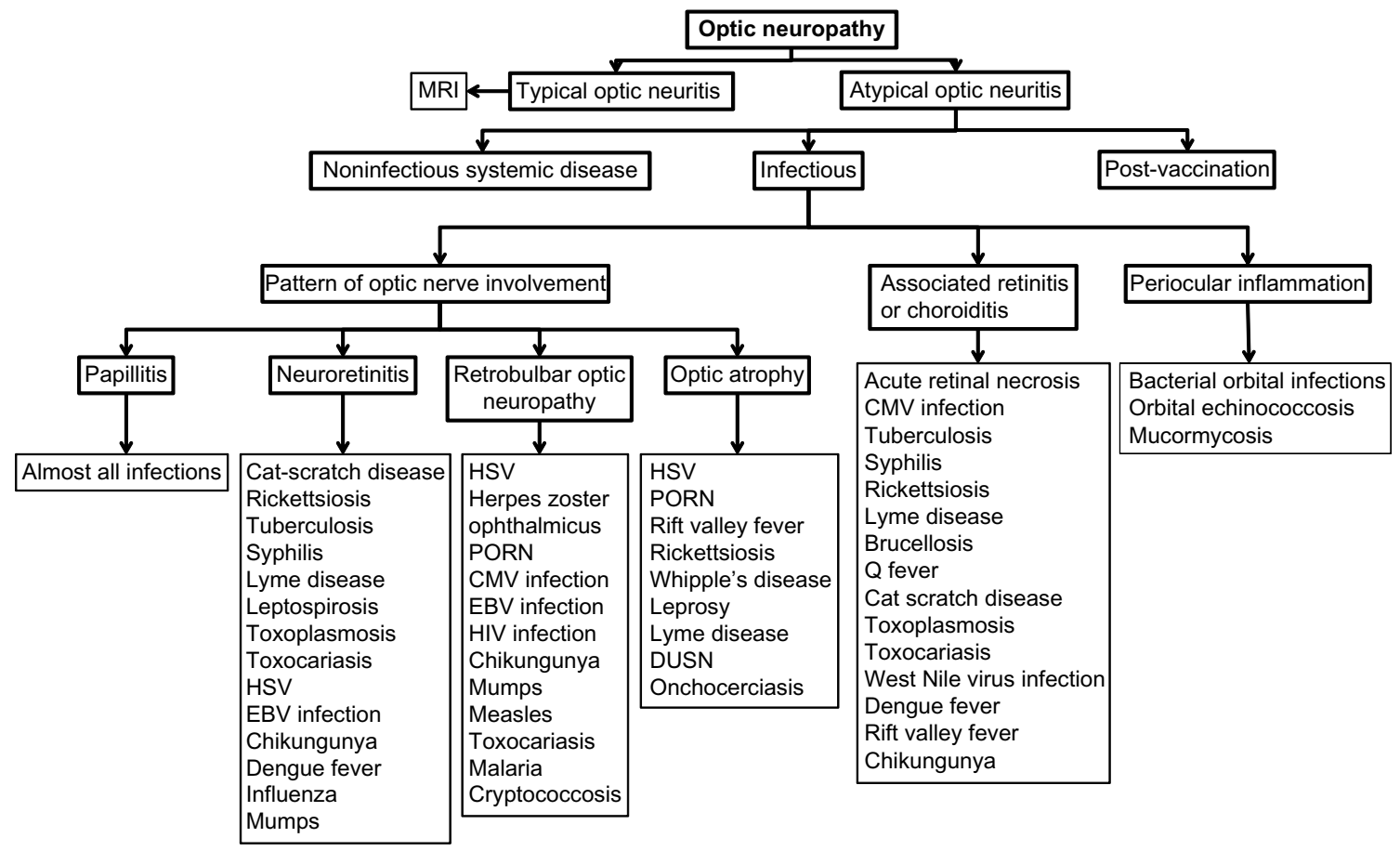

Figure 8 Practical approach to infectious optic neuropathies according to associated ocular findings.

Abbreviations: CMV, cytomegalovirus; DUSN, diffuse unilateral subacute neuroretinitis; EBV, Epstein-Barr virus; HSV, herpes simplex virus; HIV, human immunodeficiency virus; MRI, magnetic resonance imaging; PORN, progressive outer retinal necrosis.

Most cases are bilateral, and include anterior or retrobulbar optic neuritis and neuroretinitis. The overall prognosis is good, and corticosteroids may hasten visual recovery. ${ }^{284-301}$

Data from a case-control study show no increased risk of multiple sclerosis or optic neuritis following vaccination against hepatitis B, influenza, tetanus, measles, or rubella. ${ }^{302}$ Nevertheless, a possible causal relationship between vaccination against virus infection and development of optic neuritis cannot be completely excluded. ${ }^{303}$

\section{Diagnostic approach to infectious optic neuropathy}

Optic neuritis is the most common optic neuropathy, which usually affects young adults. It typically presents as an acute, unilateral inflammatory demyelinating disorder of the optic nerve that can be associated with multiple sclerosis. A gradual recovery of visual acuity with time is characteristic of optic neuritis, and the work-up should be limited to cerebromedullary magnetic resonance imaging. Atypical optic neuritis may be characterized by bilateral involvement, significant ocular inflammatory reaction, atypical clinical course, and associated systemic involvement. Atypical optic neuropathy may be associated with a wide variety of infectious (Table 1) and noninfectious disorders. Appropriate clinical diagnosis and laboratory work-up of a patient with infectious optic neuropathy are based on epidemiological data, history, the patient's immunological status, systemic symptoms and signs, and associated inflammatory involvement that may involve the adnexa, anterior segment, vitreous, retina, and choroid, as well as neuro-ophthalmological involvement (Figures 7 and 8).

Evaluation of patients with suspected infectious optic neuropathy may include a complete blood count, erythrocyte sedimentation rate, C-reactive protein, serological testing, blood cultures, PCR, or antibody assessment in aqueous humor, vitreous, serum, or cerebrospinal fluid, a tuberculin skin test and/or quantiferon, tomodensitometry, and magnetic resonance imaging.

\section{Conclusion}

A wide variety of viral, bacterial, parasitic, and fungal agents can cause optic neuropathy, with variable clinical features. Proper clinical diagnosis of any specific infectious condition is based on epidemiological data, history, systemic symptoms and signs, and the pattern of optic nerve involvement and associated ocular findings, which can be confirmed by laboratory testing. Most infectious agents can be effectively treated with specific anti-infectious drugs with or without associated corticosteroid therapy, but visual recovery is highly variable. 


\section{Acknowledgment}

This work was supported by the Ministry of Higher Education and Research of Tunisia.

\section{Author contributions}

$\mathrm{MK}, \mathrm{RK}, \mathrm{NA}, \mathrm{IK}, \mathrm{AM}, \mathrm{HZ}$, and SZ made substantial contributions to conception and design, acquisition of data, or analysis and interpretation of data. MK and RK were responsible for drafting the article or revising it critically for important intellectual content. MK, RK, NA, IK, AM, HZ, and SZ gave final approval of the version to be published. All authors contributed toward data analysis, drafting and revising the paper and agree to be accountable for all aspects of the work.

\section{Disclosure}

The authors report no conflicts of interest in this work.

\section{References}

1. Golnik KC. Infectious optic neuropathy. Semin Ophthalmol. 2002;17(1): $11-17$.

2. Bhatti MT. Optic neuropathy from viruses and spirochetes. Int Ophthalmol Clin. 2007;47(4):37-66.

3. Vaphiades M, Golnik KC. Optic neuropathy from bacteria. Int Ophthalmol Clin. 2007;47(4):25-36.

4. Lau CH, Missotten T, Salzmann J, Lightman SL. Acute retinal necrosis features, management, and outcomes. Ophthalmology. 2007;114(4): 756-762.

5. Witmer MT, Pavan PR, Fouraker BD, Levy-Clarke GA. Acute retinal necrosis associated optic neuropathy. Acta Ophthalmol. 2011;89(7): 599-607.

6. Sergott RC, Belmont JB, Savino PJ, Fischer DH, Bosley TM, Schatz NJ. Optic nerve involvement in the acute retinal necrosis syndrome. Arch Ophthalmol. 1985;103(8):1160-1162.

7. Francis PJ, Jackson H, Stanford MR, Graham EM. Inflammatory optic neuropathy as the presenting feature of herpes simplex acute retinal necrosis. Br J Ophthalmol. 2003;87(4):512-514.

8. Kang SW, Kim SK. Optic neuropathy and central retinal vascular obstruction as initial manifestations of acute retinal necrosis. Jpn J Ophthalmol. 2001;45(4):425-428.

9. Kojima M, Kimura H, Yodoi Y, Matsunaga N, Ogura Y. Preceding of optic nerve involvement in acute retinal necrosis. Retina. 2004;24(2): 297-299.

10. Stergiou PK, Konstantinou IM, Karagianni TN, Kavaki D, Printza NG. Optic neuritis caused by varicella infection in an immunocompetent child. Pediatr Neurol. 2007;37(2):138-139.

11. Galbussera A, Tagliabue E, Frigo M, Apale P, Ferrarese C, Appollonio I. Isolated bilateral anterior optic neuritis following chickenpox in an immunocompetent adult. Neurol Sci. 2006;27(4):278-280.

12. Azevedo AR, Simões R, Silva F, et al. Optic neuritis in an adult patient with chickenpox. Case Rep Ophthalmol Med. 2012;2012:371584.

13. Lee CC, Venketasubramanian N, Lam MS. Optic neuritis: a rare complication of primary varicella infection. Clin Infect Dis. 1997;24(3): 515-516.

14. Miller DH, Kay R, Schon F, McDonald WI, Haas LF, Hughes RA. Optic neuritis following chickenpox in adults. J Neurol. 1986;233(3): 182-184

15. Purvin V, Hrisomalos N, Dunn D. Varicella optic neuritis. Neurology. 1988;38(5):501-503.

16. Tappeiner C, Aebi C, Garweg JG. Retinitis and optic neuritis in a child with chickenpox: case report and review of literature. Pediatr Infect Dis J. 2010;29(12):1150-1152.
17. de Mello Vitor B, Foureaux EC, Porto FB. Herpes zoster optic neuritis. Int Ophthalmol. 2011;31(3):233-236.

18. Wang AG, Liu JH, Hsu WM, Lee AF, Yen MY. Optic neuritis in herpes zoster ophthalmicus. Jpn J Ophthalmol. 2000;44(5):550-554.

19. Kothe AC, Flanagan J, Trevino RC. True posterior ischemic optic neuropathy associated with herpes zoster ophthalmicus. Optom Vis Sci. 1990;67(11):845-849.

20. Hong SM, Yang YS. A case of optic neuritis complicating herpes zoster ophthalmicus in a child. Korean J Ophthalmol. 2010;24(2): 126-130.

21. Pakravan M, Ahmadieh H, Kaharkaboudi AR. Posterior ischemic optic neuropathy following herpes zoster ophthalmicus. J Ophthalmic Vis Res. 2009;4(1):59-62.

22. Salazar R, Russman AN, Nagel MA, et al. Varicella zoster virus ischemic optic neuropathy and subclinical temporal artery involvement. Arch Neurol. 2011;68(4):517-520.

23. Nagel MA, Russman AN, Feit H, et al. VZV ischemic optic neuropathy and subclinical temporal artery infection without rash. Neurology. 2013;80(2):220-222.

24. Engstrom RE Jr, Holland GN, Margolis TP, et al. The progressive outer retinal necrosis syndrome. A variant of necrotizing herpetic retinopathy in patients with AIDS. Ophthalmology. 1994;101(9):1488-1502.

25. Nakamoto BK, Dorotheo EU, Biousse V, Tang RA, Schiffman JS, Newman NJ. Progressive outer retinal necrosis presenting with isolated optic neuropathy. Neurology. 2004;63(12):2423-2435.

26. Patel A, Olavarria E. Optic neuritis preceding progressive outer retinal necrosis in an immunocompromised patient after allogeneic stem cell transplantation. Ann Hematol. 2013;92(10):1427-1429.

27. Mansour AM. Cytomegalovirus optic neuritis. Curr Opin Ophthalmol. 1997;8(3):55-58.

28. Mansor AM, Li HK. Cytomegalovirus optic neuritis: characteristics, therapy and survival. Ophthalmologica. 1995;209(5):260-266.

29. Patel SS, Rutzen AR, Marx JL, Thach AB, Chong LP, Rao NA. Cytomegalovirus papillitis in patients with the acquired immune deficiency syndrome: visual prognosis of patients treated with ganciclovir and/or foscarnet. Ophthalmology. 1996;103(9):1476-1482.

30. Gross JG, Sadun AA, Wiley CA, Freeman WR. Severe visual loss related to isolated peripapillary retinal and optic nerve head cytomegalovirus infection. Am J Ophthalmol. 1989;108(6):691-698.

31. Ioannidis AS, Bacon J, Frith P. Juxtapapillary cytomegalovirus retinitis with optic neuritis. J Neuroophthalmol. 2008;28(2):128-130.

32. Munteanu G, Munteanu M. [Cytomegalovirus retinitis and optic neuropathy in a case of an infectious HIV syndrome]. Oftalmologia. 1999;49(4):78-81. Romanian.

33. Cackett P, Weir CR, McFadzean R, Seaton RA. Optic neuropathy without retinopathy in AIDS and cytomegalovirus infection. J Neuroophthalmol. 2004;24(1):94-95.

34. Park KH, Bang JH, Park WB, et al. Retrobulbar optic neuritis and meningoencephalitis following progressive outer retinal necrosis due to CMV in a patient with AIDS. Infection. 2008;36(5):475-479.

35. Zheng X, Huang Y, Wang Z, Yan H, Pan S, Wang H. Presumed cytomegalovirus-associated retrobulbar optic neuritis in a patient after allogeneic stem cell transplantation. Transpl Infect Dis. 2012;14(2):177-179.

36. Baglivo E, Leuenberger PM, Krause KH. Presumed bilateral cytomegalovirus-induced optic neuropathy in an immunocompetent person. A case report. J Neuroophthalmol. 1996;16(1):14-17.

37. De Silva SR, Chohan G, Jones D, Hu M. Cytomegalovirus papillitis in an immunocompetent patient. J Neuroophthalmol. 2008;28(2):126-127.

38. Chang PY, Hamam R, Giuliari GP, Foster CS. Cytomegalovirus panuveitis associated with papillitis in an immunocompetent patient. Can J Ophthalmol. 2012;47(4):e12-e13.

39. Anderson MD, Kennedy CA, Lewis AW, Christensen GR. Retrobulbar neuritis complicating acute Epstein-Barr virus infection. Clin Infect Dis. 1994;18(5):799-801.

40. Straussberg R, Amir J, Cohen HA, Savir H, Varsano I. Epstein-Barr virus infection associated with encephalitis and optic neuritis. JPediatr Ophthalmol Strabismus. 1993;30(4):262-263. 
41. Santos-Bueso E, Sáenz-Francés F, Méndez-Hernández C, et al. [Papillitis due to Epstein-Barr virus infection in an adult patient]. Arch Soc Esp Oftalmol. 2014;89(6):245-249. Spanish.

42. Purvin V, Herr GJ, De Myer W. Chiasmal neuritis as a complication of Epstein-Barr virus infection. Arch Neurol. 1988;45(4):458-460.

43. Beiran I, Krasnitz I, Zimhoni-Eibsitz M, Gelfand YA, Miller B. Paediatric chiasmal neuritis - typical of post-Epstein-Barr virus infection? Acta Ophthalmol Scand. 2000;78(2):226-227.

44. Goldsmith P, Jones RE, Ozuzu GE, Richardson J, Ong EL. Optic neuropathy as the presenting feature of HIV infection: recovery of vision with highly active antiretroviral therapy. Br J Ophthalmol. 2000;84(5): 551-553.

45. Newman NJ, Lessell S. Bilateral optic neuropathies with remission in two HIV-positive men. J Clin Neuroophthalmol. 1992;12(1):1-5.

46. Quiceno JI, Capparelli E, Sadun AA, et al. Visual dysfunction without retinitis in patients with acquired immunodeficiency syndrome. Am J Ophthalmol. 1992;113(1):8-13.

47. Gautier D, Rabier V, Jallet G, Milea D. Visual loss related to macular subretinal fluid and cystoid macular edema in HIV-related optic neuropathy. Int Ophthalmol. 2012;32(4):405-408.

48. Larsen M, Toft PB, Bernhard P, Herning M. Bilateral optic neuritis in acute human immunodeficiency virus infection. Acta Ophthalmol Scand. 1998;76(6):737-738.

49. Le Corre A, Robin A, Maalouf T, Angioi K. [Recurrent unilateral optic neuropathy associated with human immunodeficiency virus (HIV)]. J Fr Ophtalmol. 2012;35(4):272-276. French.

50. Babu K, Murthy KR, Rajagopalan N, Satish B. Vision recovery in human immunodeficiency virus-infected patients with optic neuropathy treated with highly active antiretroviral therapy: a case series. Indian J Ophthalmol. 2009;57(4):315-318.

51. Mahadevan A, Satishchandra P, Prachet KK, et al. Optic nerve axonal pathology is related to abnormal visual evoked responses in AIDS. Acta Neuropathol. 2006;112(4):461-469.

52. Sadun AA, Pepose JS, Madigan MC, Laycock KA, Tenhula WN, Freeman WR. AIDS-related optic neuropathy: a histological, virological and ultrastructural study. Graefes Arch Clin Exp Ophthalmol. 1995; 233(7):387-398

53. Garg S, Jampol LM. Systemic and intraocular manifestations of West Nile virus infection. Surv Ophthalmol. 2005;50(1):3-13.

54. Khairallah M, Ben Yahia S, Ladjimi A, et al. Chorioretinal involvement in patients with West Nile virus infection. Ophthalmology. 2004;111(11): 2065-2070.

55. Chan CK, Limstrom SA, Tarasewicz DG, Lin SG. Ocular features of West Nile virus infection in North America: a study of 14 eyes. Ophthalmology. 2006;113(9):1539-1546

56. Khairallah M, Kahloun R. Ocular manifestations of emerging infectious diseases. Curr Opin Ophthalmol. 2013;24(6):574-580.

57. Hershberger VS, Augsburger JJ, Hutchins RK, Miller SA, Horwitz JA, Bergmann M. Chorioretinal lesions in nonfatal cases of West Nile virus infection. Ophthalmology. 2003;110(9):1732-1736.

58. Anninger WV, Lomeo MD, Dingle J, Epstein AD, Lubow M. West Nile virus-associated optic neuritis and chorioretinitis. Am J Ophthalmol. 2003;136(6):1183-1185.

59. Vaispapir V, Blum A, Soboh S, Ashkenazi H. West Nile virus meningoencephalitis with optic neuritis. Arch Intern Med. 2002;162(5): 606-607.

60. Anninger W, Lubow M. Visual loss with West Nile virus infection: a wider spectrum of a "new" disease. Clin Infect Dis. 2004;38(7):e55-e56.

61. Gilad R, Lampl Y, Sadeh M, Paul M, Dan M. Optic neuritis complicating West Nile virus meningitis in a young adult. Infection. 2003;31(1):55-56.

62. Sivakumar RR, Prajna L, Arya LK, et al. Molecular diagnosis and ocular imaging of West Nile virus retinitis and neuroretinitis. Ophthalmology. 2013;120(9):1820-1826.

63. Mahendradas P, Avadhani K, Shetty R. Chikungunya and the eye: a review. J Ophthalmic Inflamm Infect. 2013;3(1):35.

64. Lalitha P, Rathinam S, Banushree K, Maheshkumar S, Vijayakumar R, Sathe P. Ocular involvement associated with an epidemic outbreak of Chikungunya virus infection. Am J Ophthalmol. 2007;144(4): 552-556.
65. Mahendradas P, Ranganna SK, Shetty R, et al. Ocular manifestations associated with chikungunya. Ophthalmology. 2008;115(2):287-291.

66. Mittal A, Mittal S, Bharati MJ, Ramakrishnan R, Saravanan S, Sathe PS. Optic neuritis associated with chikungunya virus infection in South India. Arch Ophthalmol. 2007;125(10):1381-1386.

67. Rose N, Anoop TM, John AP, Jabbar PK, George KC. Acute optic neuritis following infection with chikungunya virus in southern rural India. Int J Infect Dis. 2011;15(2):e147-e150.

68. Mahesh G, Giridhar A, Shedbele A, Kumar R, Saikumar SJ. A case of bilateral presumed chikungunya neuroretinitis. Indian J Ophthalmol. 2009;57(2):148-150.

69. Nair AG, Biswas J, Bhende MP. A case of bilateral Chikungunya neuroretinitis. J Ophthalmic Inflamm Infect. 2012;2(1):39-40.

70. Beral L, Merle H, David T. Ocular complications of Dengue fever. Ophthalmology. 2008;115(6):1100e1

71. Ng AW, Teoh SC. Dengue eye disease. Surv Ophthalmol. 2015;60(2): 106-114.

72. Sanjay S, Wagle AM, Au Eong KG. Dengue optic neuropathy. Ophthalmology. 2009;116(1):170.

73. Haritoglou C, Dotse SD, Rudolph G, Stephan CM, Thurau SR, Klauss V. A tourist with dengue fever and visual loss. Lancet. 2002;360(9339):1070.

74. Mohindra VK, Kumari A. Unilateral optic neuritis associated with dengue fever. Delhi J Ophthalmol. 2013;23:293-294.

75. Preechawat P, Poonyathalang A. Bilateral optic neuritis after dengue viral infection. J Neuroophthalmol. 2005;25(1):51-52.

76. Sanjay S, Wagle AM, Au Eong KG. Optic neuropathy associated with dengue fever. Eye (Lond). 2008;22(5):722-724.

77. de Amorim Garcia CA, Gomes AH, de Oliveira AG. Bilateral stellar neuroretinitis in a patient with dengue fever. Eye (Lond). 2006;20(12): $1382-1383$

78. Miranda de Sousa A, Puccioni-Sohler M, Dias Borges A, Fernandes Adorno L, Papais Alvarenga M, Papais Alvarenga RM. Post-dengue neuromyelitis optica: case report of a Japanese-descendent Brazilian child. J Infect Chemother. 2006;12(6):396-398.

79. Al-Hazmi A, Al-Rajhi AA, Abboud EB, et al. Ocular complications of Rift Valley fever outbreak in Saudi Arabia. Ophthalmology. 2005; 112(2):313-318.

80. Siam AL, Meegan JM, Gharbawi KF. Rift Valley fever ocular manifestations: observations during the 1977 epidemic in Egypt. $\mathrm{Br} J$ Ophthalmol. 1980;64(5):366-374.

81. Januschowski K, Wilhelm H. [Optic neuropathy with concentric visual field constriction following life-threatening H1N1-infection]. Klin Monbl Augenheilkd. 2010;227(11):860-861. Germany.

82. Vianello FA, Osnaghi S, Laicini EA, et al. Optic neuritis associated with influenza B virus meningoencephalitis. J Clin Virol. 2014;61(3): 463-465.

83. Lai CC, Chang YS, Li ML, Chang CM, Huang FC, Tseng SH. Acute anterior uveitis and optic neuritis as ocular complications of influenza A infection in an 11-year-old boy. J Pediatr Ophthalmol Strabismus. 2011;48 Online:e30-e33.

84. Mansour DE, El-Shazly AA, Elawamry AI, Ismail AT. Comparison of ocular findings in patients with H1N1 influenza infection versus patients receiving influenza vaccine during a pandemic. Ophthalmic Res. 2012;48(3):134-138.

85. Nakamura Y, Ikeda K, Yoshii Y, et al. Influenza-associated monophasic neuromyelitis optica. Intern Med. 2011;50(15):1605-1609.

86. North DP. Ocular complications of mumps. Br J Ophthalmol. 1953; 37(2):99-101.

87. Khubchandani R, Rane T, Agarwal P, Nabi F, Patel P, Shetty AK. Bilateral neuroretinitis associated with mumps. Arch Neurol. 2002; 59(10):1633-1636.

88. Foster RE, Lowder CY, Meisler DM, Kosmorsky GS, Baetz-Greenwalt B. Mumps neuroretinitis in an adolescent. Am J Ophthalmol. 1990;110(1): 91-93.

89. Sugita K, Ando M, Minamitani K, Miyamoto H, Niimi H. Magnetic resonance imaging in a case of mumps postinfectious encephalitis with asymptomatic optic neuritis. Eur J Pediatr. 1991;150(11):773-775. 
90. Gnananayagam EJ, Agarwal I, Peter J, Prashanth P, John D. Bilateral retrobulbar neuritis associated with mumps. Ann Trop Paediatr. 2005;25(1):67-68.

91. Cansu A, Ayşe S, Sengül O, Kivilcim G, Tuğba HL. Bilateral isolated acute optic neuritis in a child after acute rubella infection. Jpn J Ophthalmol. 2005;49(5):431-433.

92. Yoshida R, Hirano Y, Izumi T, Fukuyama Y. [A case of optic neuritis following rubella encephalitis]. No To Hattatsu. 1993;25(5):442-446. Japanese.

93. Connolly JH, Hutchinson WM, Allen IV, et al. Carotid artery thrombosis, encephalitis, myelitis and optic neuritis associated with rubella virus infections. Brain. 1975;98(4):583-594.

94. Inokuchi N, Nishikawa N, Fujikado T. [Optic neuritis and measles infection]. Nippon Rinsho. 1997;55(4):861-864. Japanese.

95. Nakajima N, Ueda M, Yamazaki M, Takahashi T, Katayama Y. Optic neuritis following aseptic meningitis associated with modified measles: a case report. Jpn J Infect Dis. 2013;66(4):320-322.

96. Azuma M, Morimura Y, Kawahara S, Okada AA. Bilateral anterior optic neuritis in adult measles infection without encephalomyelitis Am J Ophthalmol. 2002;134(5):768-769.

97. Totan Y, Cekiç O. Bilateral retrobulbar neuritis following measles in an adult. Eye (Lond). 1999;13 Pt 3A:383-384.

98. Tomiyasu K, Ishiyama M, Kato K, et al. Bilateral retrobulbar optic neuritis, Guillain-Barré syndrome and asymptomatic central white matter lesions following adult measles infection. Intern Med. 2009;48(5):377-381.

99. Cunningham ET, Koehler JE. Ocular bartonellosis. Am J Ophthalmol. 2000;130(3):340-349.

100. Biancardi AL, Curi AL. Cat scratch disease. Ocul Immunol Inflamm 2014;22(2):148-154.

101. Carithers HA. Cat-scratch disease. An overview based on a study of 1,200 patients. Am J Dis Child. 1985;139(11):1124-1133.

102. Bar S, Segal M, Shapira R, Savir H. Neuroretinitis associated with cat scratch disease. Am J Ophthalmol. 1990;110(6):703-705.

103. Ormerod LD, Skolnick KA, Menosky MM, Pavan PR, Pon DM. Retinal and choroidal manifestations of cat-scratch disease. Ophthalmology. 1998;105(6):1024-1031.

104. Reed JB, Scales DK, Wong MT, Lattuada CP Jr, Dolan MJ, Schwab IR Bartonella henselae neuroretinitis in cat scratch disease. Diagnosis, management, and sequelae. Ophthalmology. 1998;105(3):459-466.

105. Chi SL, Stinnett S, Eggenberger E, et al. Clinical characteristics in 53 patients with cat scratch optic neuropathy. Ophthalmology. 2012;119(1):183-187.

106. Wade NK, Levi L, Jones MR, Bhisitkul R, Fine L, Cunningham ET Jr. Optic disk edema associated with peripapillary serous retinal detachment: an early sign of systemic Bartonella henselae infection. Am J Ophthalmol. 2000;130(3):327-334.

107. Cunningham ET Jr, McDonald HR, Schatz H, Johnson RN, Ai E, Grand MG. Inflammatory mass of the optic nerve head associated with systemic Bartonella henselae infection. Arch Ophthalmol. 1997; 115(12):1596-1597.

108. Lombardo J. Cat-scratch neuroretinitis. JAm Optom Assoc. 1999;70(8): 525-530.

109. Solley WA, Martin DF, Newman NJ, et al. Cat scratch disease: posterior segment manifestations. Ophthalmology. 1999;106(8):1546-1553.

110. Curi AL, Machado D, Heringer G, et al. Cat-scratch disease: ocular manifestations and visual outcome. Int Ophthalmol. 2010;30(5): 553-558.

111. Ormerod LD, Dailey JP. Ocular manifestations of cat-scratch disease. Curr Opin Ophthalmol. 1999;10(3):209-216.

112. Dalton MJ, Robinson LE, Cooper J, et al. Use of Bartonella antigens for serologic diagnosis of cat-scratch disease at a national referral center. Arch Intern Med. 1995;155(15):1670-1676.

113. Barka NE, Hadfield T, Patnaik M, Schwartzman WA, Peter JB. EIA for detection of Rochalimaea henselae reactive IgG, IgM, and IgA antibodies in patients with suspected cat-scratch disease (letter). J Infect Dis. 1993;167(6):1503.
114. Labalette P, Bermond D, Dedes V, Savage C. Cat-scratch disease neuroretinitis diagnosed by a polymerase chain reaction approach. Am J Ophthalmol. 2001;132(4):575-576.

115. Margileth AM. Antibiotic therapy for cat-scratch disease: clinical study of therapeutic outcome in 268 patients and a review of the literature. Pediatr Infect Dis J. 1992;11(6):474-478.

116. Rolain JM, Brouqui P, Koehler JE, et al. Recommendations for treatment of human infections caused by Bartonella species. Antimicrob Agents Chemother. 2004;48(6):1921-1933.

117. Kalogeropoulos C, Koumpoulis I, Mentis A, Pappa C, Zafeiropoulos P, Aspiotis M. Bartonella and intraocular inflammation: a series of cases and review of literature. Clin Ophthalmol. 2011;5:817-829.

118. Margileth AM. Cat scratch disease. Adv Pediatr Infect Dis. 1993;8: $1-21$.

119. Gupta V, Gupta A, Rao NA. Intraocular tuberculosis - an update. Surv Ophthalmol. 2007;52(6):561-587.

120. Gupta V, Shoughy SS, Mahajan S, et al. Clinics of ocular tuberculosis. Ocul Immunol Inflamm. 2015;23(1):14-24.

121. Davis EJ, Rathinam SR, Okada AA, et al. Clinical spectrum of tuberculous optic neuropathy. J Ophthalmic Inflamm Infect. 2012;2(4): 183-189.

122. Gupta A, Gupta V, Pandav SS, Gupta A. Posterior scleritis associated with systemic tuberculosis. Indian J Ophthalmol. 2003;51(4): 347-349

123. Amitava AK, Alarm S, Hussain R. Neuro-ophthalmic features in pediatric tubercular meningoencephalitis. J Pediatr Ophthalmol Strabismus. 2001;38(4):229-234.

124. Poon WS, Ahuja A, Li AK. Optochiasmatic tuberculoma causing progressive visual failure: when has medical treatment failed? Postgrad Med J. 1993;69(808):147-149.

125. Das JC, Singh K, Sharma P, Singla R. Tuberculous osteomyelitis and optic neuritis. Ophthalmic Surg Lasers Imaging. 2003;34(5): 409-412.

126. Stechschulte SU, Kim RY, Cunningham ET Jr. Tuberculous neuroretinitis. J Neuroophthalmol. 1999;19(3):201-204.

127. Papadia M, Herbort CP. Unilateral papillitis, the tip of the iceberg of bilateral ICGA-detected tuberculous choroiditis. Ocul Immunol Inflamm. 2011;19(2):124-126.

128. Hughes EH, Petrushkin H, Sibtain NA, Stanford MR, Plant GT, Graham EM. Tuberculous orbital apex syndromes. Br J Ophthalmol. 2008;92(11):1511-1517.

129. Schleraitzauer DA, Hodges FJ, Bagan M. Tuberculoma of the left optic nerve and chiasm. Arch Ophthalmol. 1971;85(1):75-78.

130. Iraci G, Giordano R, Gerosa M, Pardatscher K, Tomazzoli L. Tuberculoma of the anterior visual pathways. JNeurosurg. 1980;52(1): 129-133.

131. Scott RM, Sonntag VK, Wilcox LM, Adelman LS, Rockel TH. Visual loss from optochiasmatic arachnoiditis after tuberculous meningitis. J Neurosurg. 1977;46(4):524-526.

132. Caire Estévez JP, González-Ocampo Dorta S, Sanz Solana P. [Papilledema secondary to tuberculous meningitis in a patient with type 1 diabetes mellitus]. Arch Soc Esp Oftalmol. 2013;88(10):403-406. Spanish.

133. Ang M, Htoon HM, Chee SP. Diagnosis of tuberculous uveitis: clinical application of an interferon-gamma release assay. Ophthalmology. 2009;116(7):1391-1396.

134. Chao JR, Khurana RN, Fawzi AA, Reddy HS, Rao NA. Syphilis: reemergence of an old adversary. Ophthalmology. 2006;113(11): 2074-2079.

135. Peeling RW, Hook EW III. The pathogenesis of syphilis: the Great Mimicker, revisited. J Pathol. 2006;208(2):224-232.

136. Browning DJ. Posterior segment manifestations of active ocular syphilis, their response to a neurosyphilis regimen of penicillin therapy, and the influence of human immunodeficiency virus status on response. Ophthalmology. 2000;107(11):2015-2023.

137. Smith GT, Goldmeier D, Migdal C. Neurosyphilis with optic neuritis: an update. Postgrad Med J. 2006;82(963):36-39. 
138. Meehan K, Rodman J. Ocular perineuritis secondary to neurosyphilis. Optom Vis Sci. 2010;87(10):E790-E796.

139. Sacks JG, Osher RH, Elconin H. Progressive visual loss in syphilitic optic atrophy. J Clin Neuroophthalmol. 1983;3(1):5-8.

140. Arruga J, Valentines J, Mauri F, Roca G, Salom R, Rufi G. Neuroretinitis in acquired syphilis. Ophthalmology. 1985;92(2):262-270.

141. Smith JL, Byrne SF, Cambron CR. Syphiloma/gumma of the optic nerve and human immunodeficiency virus seropositivity. J Clin Neuroophthalmol. 1990;10(3):175-184.

142. Mansberger SL, MacKenzie PJ, Falardeau J. Optic disc cupping associated with neurosyphilis. J Glaucoma. 2013;22(2):80-83.

143. Gaudio PA. Update on ocular syphilis. Curr Opin Ophthalmol. 2006; 17(6):562-566

144. Cornut PL, Sobas CR, Perard L, et al. Detection of Treponema pallidum in aqueous humor by real-time polymerase chain reaction. Ocul Immunol Inflamm. 2011;19(2):127-128.

145. Centers for Disease Control and Prevention. Sexually Transmitted Diseases Treatment Guidelines, 2006. Available from: http://www. cdc.gov $/ \mathrm{mmwr} /$ preview/mmwrhtml/rr5511a1.htm. Accessed July 10, 2015.

146. Tomsak RL, Lystad LD, Katirji MB, Brassel TC. Rapid response of syphilitic optic neuritis to posterior sub-Tenon's steroid injection. J Clin Neuroophthalmol. 1992;12(1):6-7.

147. Stanek G, Wormser GP, Gray J, Strle F. Lyme borreliosis. Lancet. 2012;379(9814):461-473.

148. Mikkila HO, SeppaHi II, Viljanen MK, Peltomaa MP, Karma A. The expanding clinical spectrum of ocular Lyme borreliosis. Ophthalmology. 2000;107(3):581-587.

149. Lesser RL, Kornmehl EW, Pachner AR, et al. Neuroophthalmic manifestations of Lyme disease. Ophthalmology. 1990;97(6): 699-706.

150. Rothermel H, Hedges TR 3rd, Steer AC. Optic neuropathy in children with Lyme disease. Pediatrics. 2001;108(2):477-481.

151. Winterkorn JMS. Lyme disease: neurologic and ophthalmic manifestations. Surv Ophthalmol. 1990;35(3):191-204.

152. Karma A, Stenborg T, Summanen P, Immonen I, Mikkilä H, Seppälä I. Long-term follow-up of chronic Lyme neuroretinitis. Retina. 1996;16(6):505-509.

153. Scott IU, Silva-Lepe A, Siatkowski RM. Chiasmal optic neuritis in Lyme disease. Am J Ophthalmol. 1997;123(1):136-138.

154. Sibony P, Halperin J, Coyle PK, Patel K. Reactive Lyme serology in optic neuritis. J Neuroophthalmol. 2005;25(2):71-82.

155. Träisk F, Andersson M, Svenungsson E. Three cases of neuroborreliosis misdiagnosed as giant cell arteritis. Scand J Rheumatol. 2012;41(2): $158-160$.

156. Träisk F, Lindquist L. Optic nerve involvement in Lyme disease. Curr Opin Ophthalmol. 2012;23(6):485-490.

157. Centers for Disease Control and Prevention. Lyme disease - United States, 2003-2005. MMWR Morb Mortal Wkly Rep. 2007;56(23): 573-576.

158. McDade JE. Rickettsial diseases. In: Hausler WJ, Sussman M, editors. Topley and Wilson's Microbiology and Microbial Infections. 9th ed. London, UK: Arnold; 1998.

159. Faccini-Martínez ÁA, García-Álvarez L, Hidalgo M, Oteo JA. Syndromic classification of rickettsioses: an approach for clinical practice. Int J Infect Dis. 2014;28:126-139.

160. Khairallah M, Ladjimi A, Chakroun M, et al. Posterior segment manifestations of Rickettsia conorii infection. Ophthalmology. 2004;111(3):529-534.

161. Khairallah M, Ben Yahia S, Toumi A, et al. Ocular manifestations associated with murine typhus. Br J Ophthalmol. 2009;93(7):938-942.

162. Brooks F, Fineberg R. Ocular manifestations of typhus fever. A review of the literature from 1867 to 1943. Am J Ophthalmol. 1951;34(4): 605-608.

163. Khairallah M, Yahia SB, Attia S. Arthropod vector-borne uveitis in the developing world. Int Ophthalmol Clin. 2010;50(2):125-144.

164. Manor E, Politi F, Marmor A, Cohn DF. Papilledema in endemic typhus. Am J Ophthalmol. 1977;84(4):559-562.
165. Zhang J, Pau D, Lee AG. Postinfectious optic neuropathy in endemic typhus. J Neuroophthalmol. 2011;31(4):342-343.

166. Vaphiades MS. Rocky Mountain spotted fever as a cause of macular star figure. J Neuroophthalmol. 2003;23(4):276-278.

167. Castanet J, Costet C, Dubois D, Lacour JP, Ortonne JP. [Optic neuropathy in Mediterranean boutonneuse fever]. Presse Med. 1988;17(9): 439-440. French.

168. Granel B, Serratrice J, Rey J, Conrath J, Disdier P, Weiller PJ. Baisse de l'acuité visuelle au cours d'une fièvre boutonneuse méditerranéenne. [Impaired visual acuity in Mediterranean boutonneuse fever]. Presse Med. 2001;30(17):859. French.

169. Khairallah M, Zaouali S, Ben Yahia S, et al. Anterior ischemic optic neuropathy associated with rickettsia conorii infection. J Neuroophthalmol. 2005;25(3):212-214.

170. Espino Barros Palau A, Morgan ML, Lee AG. Bilateral optic atrophy in endemic typhus. Can J Ophthalmol. 2014;49(4):e90-e92.

171. Kahloun R, Gargouri S, Abroug N, et al. Visual loss associated with rickettsial disease. Ocul Immunol Inflamm. 2014;22(5):373-378.

172. Maurin M, Raoult D. Q fever. Clin Microbiol Rev. 1999;12(4): $518-553$.

173. Matonti F, Conrath J, Bodaghi B, Le Hoang P, Raoult D, Drancourt M. Uveitis in the course of Q-fever. Clin Microbiol Infect. 2009;15 Suppl2: 176-177.

174. Kerkhof E, Weersink A, Rothova A. Coxiella burnetii infection, a potential cause of neuroretinitis: two case reports and literature review. Retin Cases Brief Rep. 2007;1:17-19.

175. Alajouanine T, Lhermitte F, Clay R, Corbin J. [Polyradiculoneuritis with albuminocytological dissociation during $\mathrm{Q}$ fever]. Bull Mem Soc Med Hop Paris. 1960;76:329-331. French.

176. Catros A, Hoel J. [Bilateral axial optic neuritis caused by Q fever]. Bull Soc Ophtalmol Fr. 1960;5:325-330. French.

177. Schuil J, Richardus JH, Baarsma GS, Schaap GJ. Q fever as a possible cause of bilateral optic neuritis. Br J Ophthalmol. 1985;69(8): $580-583$.

178. Shaked Y, Samra Y. Q fever meningoencephalitis associated with bilateral abducens nerve paralysis, bilateral optic neuritis and abnormal cerebrospinal fluid findings. Infection. 1989;17:394-395.

179. Ong C, Ahmad O, Senanayake S, Buirski G, Lueck C. Optic neuritis associated with Q fever: case report and literature review. Int $J$ Infect Dis. 2010;14 Suppl 3:e269-e273.

180. Million M, Halfon J, Le Lez ML, Drancourt M, Raoult D. Relapsing uveitis and optic neuritis due to chronic Q fever. Br J Ophthalmol. 2011;95(7):1026-1027.

181. Durand DV, Lecomte C, Cathebras P, Rousset H, Godeau P. Whipple disease. Clinical review of 52 cases. The SNFMI Research Group on Whipple Disease. Société Nationale Française de Médecine Interne. Medicine (Baltimore). 1997;76(3):170-184.

182. Chan RY, Yannuzzi LA, Foster CS. Ocular Whipple's disease: earlier definitive diagnosis. Ophthalmology. 2001;108(12):2225-2231.

183. Touitou V, Fenollar F, Cassoux N, et al. Ocular Whipple's disease: therapeutic strategy and long-term follow-up. Ophthalmology. 2012;119(7):1465-1469.

184. Lieger O, Otto S, Clemetson IA, Arnold M, lizuka T. Orbital manifestation of Whipple's disease: an atypical case. J Craniomaxillofac Surg. 2007;35(8):393-396.

185. Switz DM, Casey TR, Bogaty GV. Whipple's disease and papilledema. An unreported presentation. Arch Intern Med. 1969;123(1):74-77.

186. Alton GG, Jones LM, Pietz DE. Laboratory Techniques in Brucellosis. 2nd ed. Geneva, Switzerland: World Health Organization; 1975.

187. Fraunfelder FT, Roy FH, Randall J. Current Ocular Therapy. 5th ed. Philadelphia, PA, USA: WB Saunders Company; 2000.

188. Solanes MP, Heatley J, Arenas F, Ibarra GG. Ocular complications in brucellosis. Am J Ophthalmol. 1953;36(5):675-689.

189. Al-Kaff AS. Ocular brucellosis. Int Ophthalmol Clin. 1995;35(3): 139-145.

190. Gungur K, Bekir NA, Namiduru M. Ocular complications associated with brucellosis in an endemic area. Eur J Ophthalmol. 2002;12(3): $232-237$. 
191. Tabbarra KF, Al-Kassimi H. Ocular brucellosis. Br J Ophthalmol. 1990;74(4):249-250.

192. Rolando I, Olarte L, Vilchez G, et al. Ocular manifestations associated with brucellosis: a 26-year experience in Peru. Clin Infect Dis. 2008;46(9):1338-1345.

193. Sungur GK, Hazirolan D, Gurbuz Y, Unlu N, Duran S, Duman S. Ocular involvement in brucellosis. Can J Ophthalmol. 2009;44(5): 598-601.

194. Walker J, Sharma OP, Rao NA. Brucellosis and uveitis. Am J Ophthalmol. 1992;114(3):374-375.

195. Cavallaro N, Randone A, La Rosa L, Mughinin L. Bilateral papilledema in a patient with brucellosis. Metab Pediatr Syst Ophthalmol. 1990;13(2-4):115-118.

196. Abd Elrazak M. Brucella optic neuritis. Arch Intern Med. 1991;151(4): 776-778.

197. Kidd D, Burton B, Plant GT, Graham EM. Chronic relapsing inflammatory optic neuropathy. Brain. 2003;126 Pt 2:276-284.

198. Karakurum Goksel B, Yerdelen D, Karatas M, et al. Abducens nerve palsy and optic neuritis as initial manifestation in brucellosis. Scand J Infect Dis. 2006;38(8):721-725.

199. Tunc M, Durukan H. Bilateral severe visual loss in brucellosis. Ocul Immunol Inflamm. 2004;12(3):233-236.

200. Romero M, Sanchez F, Fernandez-Bolanos R, Jimenez MD. [Optic neuritis as a clinical manifestation of neurobrucellosis]. Rev Neurol. 1999;28(4):438. Spanish.

201. Rathinam SR, Namperumalsamy P. Leptospirosis. Ocular Immunol Inflamm. 1999;7(2):109-118.

202. Rathinam SR. Ocular leptospirosis. Curr Opin Ophthalmol. 2002; 13(6):381-386.

203. Rathinam SR. Ocular manifestations of leptospirosis. J Postgrad Med. 2005;51(3):189-194.

204. Martins MG, Matos KT, da Silva MV, de Abreu MT. Ocular manifestations in the acute phase of leptospirosis. Ocular Immunol Inflamm. 1998;6(2):75-79.

205. Rathinam SR, Rathnam S, Selvaraj S, Dean D, Nozik RA, Namperumalsamy P. Uveitis associated with an epidemic outbreak of leptospirosis. Am J Ophthalmol. 1997;124(1):71-79.

206. Levin N, Nguyen-Khoa JL, Charpentier D, Strobel M, FourniéAmazouz E, Denis P. Panuveitis with papillitis in leptospirosis. Am J Ophthalmol. 1994;117(1):118-1119.

207. Mancel E, Merien F, Pesenti L. Clinical aspects of ocular leptospirosis in New Caledonia (South Pacific). Aust N Z J Ophthalmol. 1999;27(6):380-386.

208. Parikh R, Thomas S, Muliyil J, Parikh S, Thomas R. Ocular manifestation in treated multibacillary Hansen's disease. Ophthalmology. 2009;116(11):2051-2057.

209. Choyce DP. Diagnosis and management of ocular leprosy. Br J Ophthalmol. 1969;53(4):217-223.

210. Lee SB, Lee EK, Kim JY. Bilateral optic neuritis in leprosy. Can J Ophthalmol. 2009;44(2):219-220.

211. Prabha N, Mahajan VK, Sharma SK, et al. Optic nerve involvement in a borderline lepromatous leprosy patient on multidrug therapy. Lepr Rev. 2013;84(4):316-321.

212. Colarizi A, Panico E. Atrofi a secondaria del nervo ottico consecutiva a infezione carbonchiosa. [Secondary atrophy of the optic nerve consecutive to anthrax]. Bull Acad Med Roma. 1933;59:399-408. Italian.

213. Smallberg GJ, Sherman SH, Pezeshkpour GH, Lisak RP. Optic neuropathy due to brain abscess. Am J Ophthalmol. 1976;82(2):188-192.

214. Ellsworth J, Marks MI, Vose A. Meningococcal meningitis in children. Can Med Assoc J. 1979;120(2):155-158.

215. Miller HG, Staton JB, Gibbons JL. Parainfectious encephalomyelitis and related syndromes: a critical review of the neurological complications of certain specific fevers. Q J Med. 1956;25(100):427-505.

216. Bajpai PC, Dikshit SK. Bilateral optic neuritis and encephalitis accompanying typhoid. J Indian Med Assoc. 1958;30(2):54-57.

217. Lee HS, Choi KD, Lee JE, Park HK. Optic neuritis after Klebsiella pneumonitis and liver abscess. J Neuroophthalmol. 2009;29(2): 134-135.
218. Vécsei PV, Kircher K, Reitner A, Khanakha G, Stanek G. Chlamydia in anterior ischemic optic neuropathy. Ophthalmologica. 2002;216(3):215-220.

219. Subbotina IN, Gorovits ES, Timasheva OA. [Case of uveoneuritis caused by Chlamydia]. Vestn Oftalmol. 1982;(1):61-63. Russian.

220. Guo ZN, Zhang HL, Bai J, Wu J, Yang Y. Meningitis associated with bilateral optic papillitis following Mycoplasma pneumoniae infection. Neurol Sci. 2012;33(2):355-358.

221. Sagui E, Chazalon E, Bregigeon M, Oliver M, Brosset C. [Optic neuritis attributable to Mycoplasma pneumoniae]. Rev Neurol (Paris). 2007;163(11):1103-1105. French.

222. Ginestal RC, Plaza JF, Callejo JM, Rodríguez-Espinosa N, FernándezRuiz LC, Masjuán J. Bilateral optic neuritis and Guillain-Barré syndrome following an acute Mycoplasma pneumoniae infection. J Neurol. 2004;251(6):767-768.

223. Chaudhry IA, Al-Rashed W, Arat YO. The hot orbit: orbital cellulitis. Middle East Afr J Ophthalmol. 2012;19(1):34-42.

224. Chandler JR, Langenbrunner DJ, Stevens ER. The pathogenesis of orbital complications in acute sinusitis. Laryngoscope. 1970;80(9): 1414-1428.

225. Slavin ML, Glaser JS. Acute severe irreversible visual loss with sphenoethmoiditis - 'posterior' orbital cellulitis. Arch Ophthalmol. 1987;105(3):345-348.

226. Chaudhry IA, Shamsi FA, Elzaridi E, et al. Outcome of treated orbital cellulitis in a tertiary eye care center in the Middle East. Ophthalmology. 2007;114(2):345-354.

227. Vasconcelos-Santos DV. Ocular manifestations of systemic disease: toxoplasmosis. Curr Opin Ophthalmol. 2012;23(6):543-550.

228. Eckert GU, Melamed J, Menegaz B. Optic nerve changes in ocular toxoplasmosis. Eye (Lond). 2007;21(6):746-751.

229. Shenoy R, Al Hinai A. Presumed ocular toxoplasmosis presenting as papillitis. Indian J Ophthalmol. 2003;51(4):357-359.

230. Küçükerdönmez C, Akova YA, Yilmaz G. Ocular toxoplasmosis presenting as neuroretinitis: report of two cases. Ocul Immunol Inflamm. 2002;10(3):229-234.

231. Moreno RJ, Weisman J, Waller S. Neuroretinitis: an unusual presentation of ocular toxoplasmosis. Ophthalmology. 1992;24(2):68-70.

232. Fish RH, Hoskins JC, Kline LB. Toxoplasmosis neuroretinitis. Ophthalmology. 1993;100(8):1177-1182.

233. Perrotta S, Nobili B, Grassia C, Sebastiani A, Parmeggiani F, Costagliola C. Bilateral neuroretinitis in a 6-year-old boy with acquired toxoplasmosis. Arch Ophthalmol. 2003;121(10):1493-1496.

234. Roach ES, Zimmerman CF, Troost BT, Weaver RG. Optic neuritis due to acquired toxoplasmosis. Pediatr Neurol. 1985;1(2):114-116.

235. Folk JC, Lobes LA. Presumed toxoplasmic papillitis. Ophthalmology. 1984;91(1):64-67.

236. Banta JT, Davis JL, Lam BL. Presumed toxoplasmic anterior optic neuropathy. Ocul Immunol Inflamm. 2002;10(3):201-211.

237. Song A, Scott IU, Davis JL, Lam BL. Atypical anterior optic neuropathy caused by toxoplasmosis. Am J Ophthalmol. 2002;133(1): 162-164.

238. Alipanahi R, Sayyahmelli S. Acute papillitis in young female with toxoplasmosis. Middle East Afr J Ophthalmol. 2011;18(3):249-251.

239. Küçükerdönmez C, Akova YA, Yilmaz G. Ocular toxoplasmosis presenting as neuroretinitis: report of two cases. Ocul Immunol Inflamm. 2002;10(3):229-234.

240. Stanford MR, Tomlin EA, Comyn O, Holland K, Pavesio C. The visual field in toxoplasmic retinochoroiditis. Br J Ophthalmol. 2005;89(7): $812-814$

241. Ament CS, Young LH. Ocular manifestations of helminthic infections: onchocersiasis, cysticercosis, toxocariasis, and diffuse unilateral subacute neuroretinitis. Int Ophthalmol Clin. 2006;46(2):1-10.

242. Sabrosa NA, Zajdenweber M. Nematode infections of the eye: toxocariasis, onchocerciasis, diffuse unilateral subacute neuroretinitis, and cysticercosis. Ophthalmol Clin North Am. 2002;15(3):351-356.

243. Komiyama A, Hasegawa O, Nakamura S, Ohno S, Kondo K. Optic neuritis in cerebral toxocariasis. J Neurol Neurosurg Psychiatry. 1995; 59(2):197-198. 
244. Cox TA, Haskins GE, Gangitano JL, Antonson DL. Bilateral Toxocara optic neuropathy. J Clin Neuroophthalmol. 1983;3(4):267-274.

245. Molk R. Treatment of toxocaral optic neuritis. J Clin Neuroophthalmol. 1982;2(2):109-112.

246. Margo CE, Sedwick LA, Rubin ML. Neuroretinitis in presumed visceral larva migrans. Retina. 1986;6(2):95-98.

247. Brown GC, Tasman WS. Retinal arterial obstruction in association with presumed Toxocara canis neuroretinitis. Ann Ophthalmol. 1981;13(12):1385-1387.

248. Stewart JM, Cubillan LD, Cunningham ET Jr. Prevalence, clinical feature, and causes of vision loss among patients with ocular toxocariasis. Retina. 2005;25(8):1005-1013.

249. Chelnis J, Selvadurai AD, Fasiuddin A. Enhanced depth imaging and fundus autofluorescence of Toxocara optic nerve granuloma. Ocul Immunol Inflamm. 2013;21(1):82-83.

250. Ament CS, Young LH. Ocular manifestations of helminthic infections: onchocersiasis, cysticercosis, toxocariasis, and diffuse unilateral subacute neuroretinitis. Int Ophthalmol Clin. 2006;46(2):1-10.

251. de Amorim Garcia Filho CA, Gomes AH, de A Garcia Soares AC, de Amorim Garcia CA. Clinical features of 121 patients with diffuse unilateral subacute neuroretinitis. Am J Ophthalmol. 2012;153(4): 743-749.

252. Souza EC, Casella AM, Nakashima Y, Monteiro ML. Clinical features and outcomes of patients with diffuse unilateral subacute neuroretinitis treated with oral albendazole. Am J Ophthalmol. 2005;140(3): 437-445.

253. Ament CS, Young LH. Ocular manifestations of helminthic infections: onchocersiasis, cysticercosis, toxocariasis, and diffuse unilateral subacute neuroretinitis. Int Ophthalmol Clin. 2006;46(2):1-10.

254. Kochar DK, Shubhakaran, Kumawat BL, Thanvi I, Joshi A, Vyas SP. Ophthalmoscopic abnormalities in adults with falciparum malaria. QJM. 1998;91(12):845-852.

255. Chacko JG, Onteddu S, Rosenbaum ER. Bilateral optic neuritis due to malaria. J Neuroophthalmol. 2013;33(3):266-267.

256. Kale VP, Bichile LS, Bajpai S. Falciparum malaria induced retrobulbar neuritis. J Postgrad Med. 2004;50(2):150.

257. Wadia PZ. Retrobulbar neuritis in two patients with falciparum malaria. J Assoc Physicians India. 1990;38(10):800-801.

258. Feng Y, Nawa Y, Sawanyavisuth K, Lv Z, Wu ZD. Comprehensive review of ocular angiostrongyliasis with special reference to optic neuritis. Korean J Parasitol. 2013;51(6):613-619.

259. Sinawat S, Yospaiboon Y, Sinawat S. Subretinal angiostrongyliasisinduced optic neuritis. Clin Ophthalmol. 2013;7:977-979.

260. Sawanyawisuth K, Kitthaweesin K. Optic neuritis caused by intraocular angiostrongyliasis. Southeast Asian J Trop Med Public Health. 2008;39(6):1005-1007.

261. Sinawat S, Sanguansak T, Angkawinijwong T, et al. Ocular angiostrongyliasis: clinical study of three cases. Eye (Lond). 2008; 22(11):1446-1448.

262. Wang LC, Wang IH, Jou JR. Optic neuritis secondary to Angiostrongylus cantonensis infection. Ocul Immunol Inflamm. 2006;14(3):189-191.

263. Murthy R, Honavar SG, Vemuganti GK, et al. Polycystic echinococcosis of the orbit. Am J Ophthalmol. 2005;140(3):561-563.

264. Kumar J, Sahay CB, Kumar A. Recurrent primary retro-bulbar hydatid cysts. Asian J Neurosurg. 2014;9(4):242.

265. Bagheri A, Fallahi MR, Yazdani S, Rezaee Kanavi M. Two different presentations of orbital echinococcosis: a report of two cases and review of the literature. Orbit. 2010;29(1):51-56.

266. Golnik KC, Newman SA, Wispelway B. Cryptococcal optic neuropathy in the acquired immune deficiency syndrome. J Clin Neuroophthalmol. 1991;11(2):96-103.

267. Portelinha J, Passarinho MP, Almeida AC, Costa JM. Bilateral optic neuropathy associated with cryptococcal meningitis in an immunocompetent patient. BMJ Case Rep. June 11, 2014. [Epub ahead of print.]

268. Cohen DB, Glasgow BJ. Bilateral optic nerve cryptococcosis in sudden blindness in patients with acquired immune deficiency syndrome. Ophthalmology. 1993;100(11):1689-1694.
269. Lipson BK, Freeman WR, Beniz J, et al. Optic neuropathy associated with cryptococcal arachnoiditis in AIDS patients. Am J Ophthalmol. 1989;107(5):523-527.

270. Rex JH, Larsen RA, Dismukes WE, Cloud GA, Bennett JE. Catastrophic visual loss due to Cryptococcus neoformans meningitis. Medicine (Baltimore). 1993;72(4):207-224.

271. Garrity JA, Herman DC, Imes R, Fries P, Hughes CF, Campbell RJ. Optic nerve sheath decompression for visual loss in patients with acquired immunodeficiency syndrome and cryptococcal meningitis with papilledema. Am J Ophthalmol. 1993;116(4):472-478.

272. Rao NA, Hidayat AA. Endogenous mycotic endophthalmitis: variations in clinical and histopathologic changes in candidiasis compared with aspergillosis. Am J Ophthalmol. 2001;132(2):244-251.

273. Shah CP, McKey J, Spirn MI, Maguire J. Ocular candidiasis: a review. Br J Ophthalmol. 2008;92(4):466-468.

274. Oliver A, Ciulla TA, Comer GM. New and classic insights into presumed ocular histoplasmosis syndrome and its treatment. Curr Opin Ophthalmol. 2005;16(3):160-165.

275. Choi MY, Bae IH, Lee JH, Lee SJ. Aspergillosis presenting as an optic neuritis. Korean J Ophthalmol. 2002;16(2):119-123.

276. Weinstein JM, Sattler FA, Towfighi J, Sassani J, Page RB. Optic neuropathy and paratrigeminal syndrome due to Aspergillus fumigatus. Arch Neurol. 1982;39(9):582-585.

277. Weinstein JM, Morris GL, ZuRhein GM, Gentry LR. Posterior ischemic optic neuropathy due to Aspergillus fumigatus. J Clin Neuroophthalmol. 1989;9(1):7-13.

278. Spoor TC, Hartel WC, Harding S, Kocher G. Aspergillosis presenting as a corticosteroid-responsive optic neuropathy. J Clin Neuroophthalmol. 1982;2(2):103-107.

279. Matsuo T, Notohara K, Yamadori I. Aspergillosis causing bilateral optic neuritis and later orbital apex syndrome. Jpn J Ophthalmol. 2005;49(5):430-431.

280. Nithyanandam S, Jacob MS, Battu RR, Thomas RK, Correa MA, D'Souza O. Rhino-orbito-cerebral mucormycosis. A retrospective analysis of clinical features and treatment outcomes. Indian $J$ Ophthalmol. 2003;51(3):231-236.

281. Alsuhaibani AH, Al-Thubaiti G, Al Badr FB. Optic nerve thickening and infarction as the first evidence of orbital involvement with mucormycosis. Middle East Afr J Ophthalmol. 2012;19(3):340-342.

282. Mathur S, Karimi A, Mafee MF. Acute optic nerve infarction demonstrated by diffusion-weighted imaging in a case of rhinocerebral mucormycosis. AJNR Am J Neuroradiol. 2007;28(3):489-490.

283. Lee BL, Holland GN, Glasgow BJ. Chiasmal infarction and sudden blindness caused by mucormycosis in AIDS and diabetes mellitus. Am J Ophthalmol. 1996;122(6):895-896.

284. Crawford CM, Grazko MB, Raymond WR 4th, Rivers BA, Munson PD. Retrobulbar optic neuritis and live attenuated influenza vaccine. J Pediatr Ophthalmol Strabismus. 2013;50(1):61.

285. Lapphra K, Huh L, Scheifele DW. Adverse neurologic reactions after both doses of pandemic H1N1 influenza vaccine with optic neuritis and demyelination. Pediatr Infect Dis J. 2011;30(1):84-86.

286. Kawasaki A, Purvin VA, Tang R. Bilateral anterior ischemic optic neuropathy following influenza vaccination. $J$ Neuroophthalmol. 1998;18(1):56-59.

287. Liang XF, Li L, Liu DW, et al. Safety of influenza A (H1N1) vaccine in postmarketing surveillance in China. $N$ Engl J Med. 2011;364(7): 638-647.

288. Erguven M, Guven S, Akyuz U, Bilgiç O, Laloglu F. Optic neuritis following hepatitis B vaccination in a 9-year-old girl. $J$ Chin Med Assoc. 2009;72(11):594-597.

289. Voigt U, Baum U, Behrendt W, Hegemann S, Terborg C, Strobel J. [Neuritis of the optic nerve after vaccinations against hepatitis A, hepatitis B and yellow fever]. Klin Monbl Augenheilkd. 2001;218(10): 688-690. German.

290. Saxena R, Sethi HS, Rai HK, Menon V. Bilateral neuro-retinitis following chick embryo cell anti-rabies vaccination - a case report. $B M C$ Ophthalmol. 2005;5:20. 
291. Dadeya S, Guliani BP, Gupta VS, Malik KP, Jain DC. Retrobulbar neuritis following rabies vaccination. Trop Doct. 2004;34(3): $174-175$.

292. Gupta V, Bandyopadhyay S, Bapuraj JR, Gupta A. Bilateral optic neuritis complicating rabies vaccination. Retina. 2004;24(1):179-181.

293. Moradian S, Ahmadieh H. Early onset optic neuritis following measlesrubella vaccination. J Ophthalmic Vis Res. 2008;3(2):118-122.

294. Arshi S, Sadeghi-Bazargani H, Ojaghi H, et al. The first rapid onset optic neuritis after measles-rubella vaccination: case report. Vaccine. 2004;22(25-26):3240-3242.

295. Cansu A, Ayşe S, Sengül O, Kivilcim G, Tuğba HL. Bilateral isolated acute optic neuritis in a child after acute rubella infection. Jpn J Ophthalmol. 2005;49(5):431-433.

296. Payne DC, Rose CE Jr, Kerrison J, Aranas A, Duderstadt S, McNeil MM. Anthrax vaccination and risk of optic neuritis in the United States military, 1998-2003. Arch Neurol. 2006;63(6):871-875.

297. Kerrison JB, Lounsbury D, Thirkill CE, Lane RG, Schatz MP, Engler RM. Optic neuritis after anthrax vaccination. Ophthalmology. 2002;109(1):99-104.
298. Burkhard C, Choi M, Wilhelm H. [Optic neuritis as a complication in preventive tetanus-diphtheria-poliomyelitis vaccination: a case report] Klin Monbl Augenheilkd. 2001;218(1):51-54. German.

299. McReynolds WU, Havener WH, Petrohelos MA. Bilateral optic neuritis following smallpox vaccination and diphtheria-tetanus toxoid. AMA Am J Dis Child. 1953;86(5):601-603.

300. Topaloglu H, Berker M, Kansu T, Saatci U, Renda Y. Optic neuritis and myelitis after booster tetanus toxoid vaccination. Lancet. 1992;339(8786):178-179.

301. DiMario FJ Jr, Hajjar M, Ciesielski T. A 16-year-old girl with bilateral visual loss and left hemiparesis following an immunization against human papilloma virus. J Child Neurol. 2010;25(3):321-327.

302. DeStefano F, Verstraeten T, Jackson LA, et al. Vaccine Safety Datalink Research Group, National Immunization Program, Centers for Disease Control and Prevention. Vaccinations and risk of central nervous system demyelinating diseases in adults. Arch Neurol. 2003;60(4):504-509.

303. Stübgen JP. A literature review on optic neuritis following vaccination against virus infections. Autoimmun Rev. 2013;12(10):990-997.
Eye and Brain

\section{Publish your work in this journal}

Eye and Brain is an international, peer-reviewed, open access journal focusing on clinical and experimental research in the field of neuro-ophthalmology. All aspects of patient care are addressed within the journal as well as basic research. Papers covering original research, basic science, clinical and epidemiological studies, reviews and

\section{Dovepress}

evaluations, guidelines, expert opinion and commentary, case reports and extended reports are welcome. The manuscript management system is completely online and includes a very quick and fair peer-review system, which is all easy to use. Visit http://www.dovepress.com/testimonials.php to read real quotes from published authors. 